\title{
Recharge Rates to the Upper Floridan Aquifer in the Suwannee River Water Management District, Florida
}

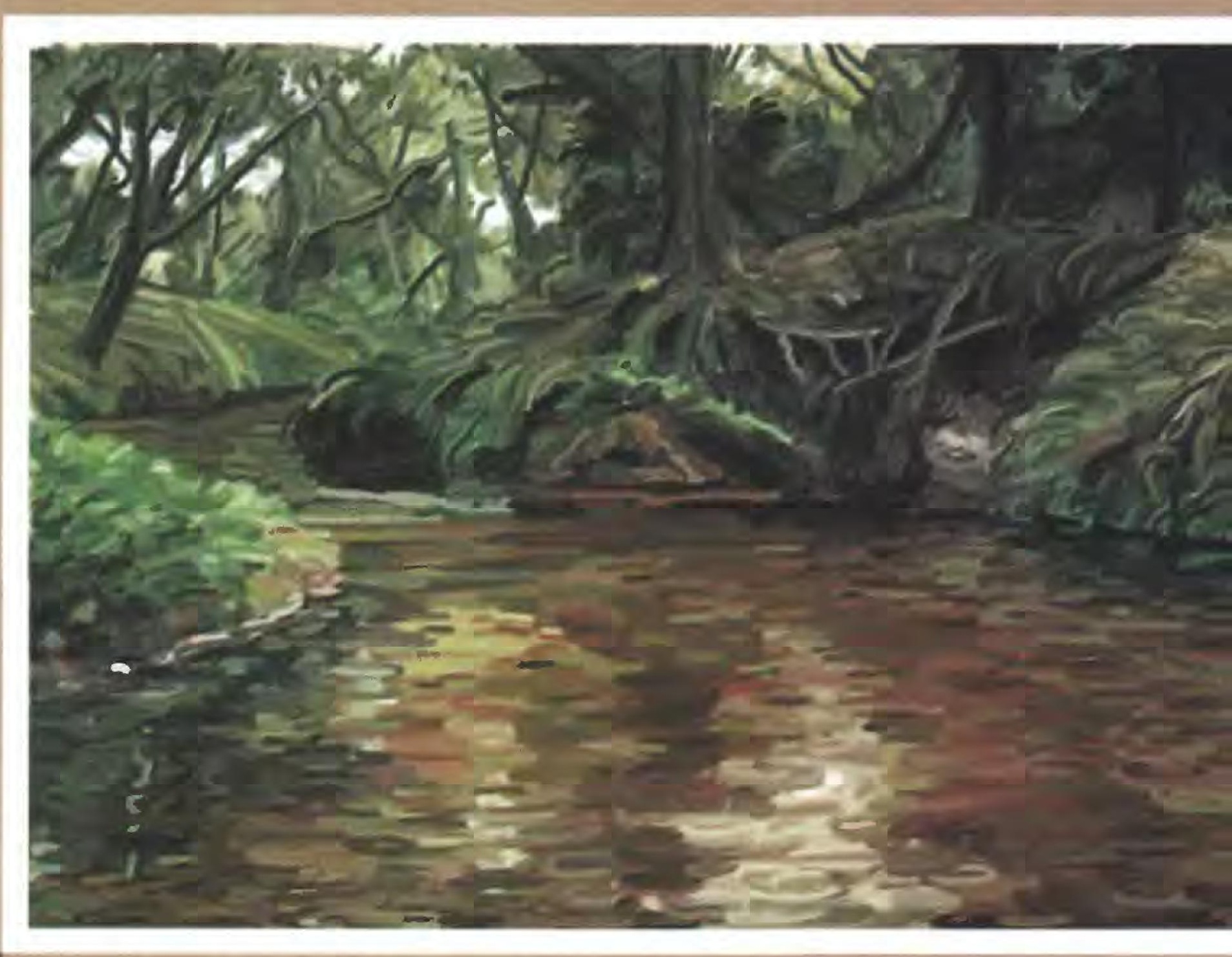

\section{U.S. GEOLOGICAL SURVEY}

Water-Resources Investigations Report 97-4283

Prepared in cooperation with the Suwannee River Water Management District 


\section{Recharge Rates to the Upper Floridan Aquifer in the Suwannee River Water Management District, Florida}

By J.W. Grubbs

U.S. GEOLOGICAL SURVEY

Water-Resources Investigations Report 97-4283

Prepared in cooperation with the

Suwannee River Water Management District

Tallahassee, Florida 


\title{
U.S. DEPARTMENT OF THE INTERIOR BRUCE BABBITT, Secretary
}

\author{
U.S. GEOLOGICAL SURVEY
}

Mark Schaefer, Acting Director

The use of firm, trade, and brand names in this report is for identification purposes only and does not constitute endorsement by the U.S. Geological Survey.

For addtional information write to:

Copies of this report can be purchased from:

District Chief

U.S. Geological Survey

227 North Bronough Street, Suite 3015

Tallahassee, FL 32301
U.S. Geological Survey

Branch of Information Services

Box 25286, MS 517

Denver, CO 80225-0046 


\section{CONTENTS}

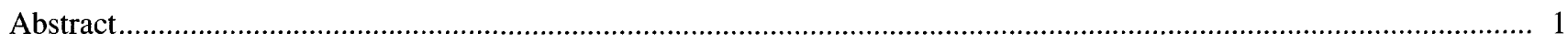

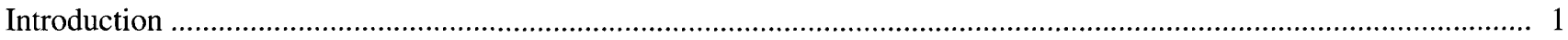

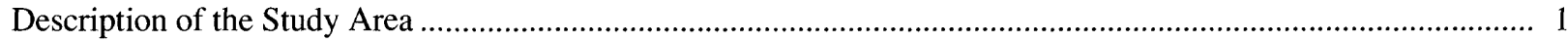

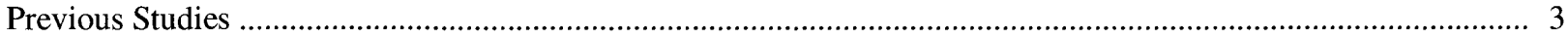

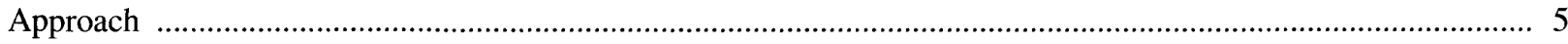

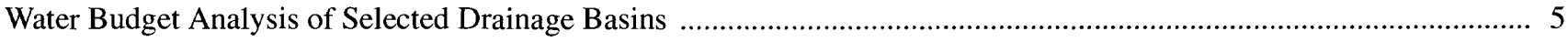

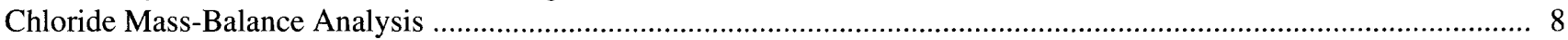

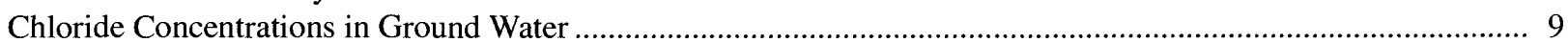

Rates of Atmospheric Deposition of Chloride ....................................................................................

Comparison of Atmospheric Deposition of Chloride with Chloride Concentrations in Ground Water ...................14

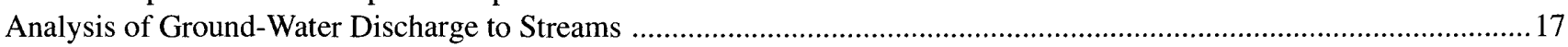

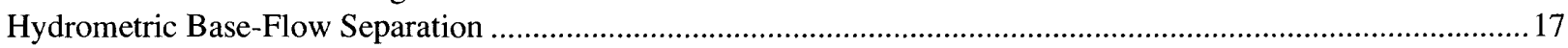

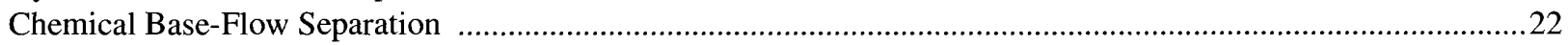

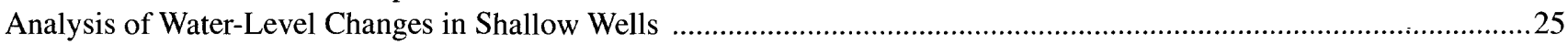

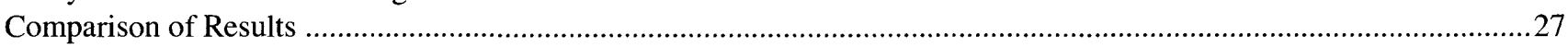

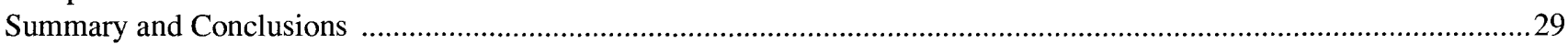

References

\section{FIGURES}

1. Map showing location and physiographic areas of the Suwannee River Water Management District ................... 2

2. Map showing confinement of the Upper Floridan aquifer in the Suwannee River Water Management District....... 4

3. Conceptual diagram of water flows in the Suwannee River Water Management District .................................. 7

4-8. Map showing:

4. The locations of gaging stations used in the water budget or base flow analyses ........................................ 10

5. Chloride concentrations in ground water in the Suwannee River Water Management District ........................11

6. Atmospheric deposition rates of chloride in the Suwannee River Water Management District .......................12

7. Recharge rates computed from chloride concentrations in ground water and atmospheric deposition rates of chloride

8. The potentiometric surface of the Upper Floridan aquifer in the Suwannee River Water Management District in May and June 1995

9. Graphs showing the relation between aquifer confinement and recharge in selected ground-water basins in the Suwannee River Water Management District.

10. Graphs showing the relation between specific conductance and stream discharge in the Santa Fe River at sites 13 (near Worthington Springs) and 17 (near Fort White)

11. Diagram showing the relation between recharge, ground-water drainage from recharge area and movement of water table

12. Graph showing the relation between ground-water level and ground-water level recession rate at the Alto Straughn well

13. Boxplots showing distributions of monthly recharge, precipitation, and recharge efficiency (recharge divided by precipitation) at the Alto Straughn well 


\section{TABLES}

1. Results of water budget analyses of selected drainage basins .................................................................. 8

2. Atmospheric deposition in or near the Suwannee River Water Management District .............................................. 13

3. Recharge estimates from chloride mass-balance analysis .................................................................................. 14

4. Total runoff and ground-water runoff at individual streamflow stations ........................................................... 18

5. Change in total runoff and ground-water runoff between selected streamflow stations .......................................... 21

6. Data used to develop regression model relating recharge to confinement of the Upper Floridan aquifer ....................22

7. Results from regression analysis of aquifer recharge and aquifer confinement ..................................................... 24

8. Data and results of the chemical base-flow separation analysis of the Santa Fe River between the Worthington Springs (site 13) and Fort White (site 17) gaging stations

9. Recharge estimates for confined, poorly confined, and unconfined areas in the Suwannee River Water Management District 


\title{
Recharge Rates To The Upper Floridan Aquifer in the Suwannee River Water Management District, Florida
}

\author{
By J.W. Grubbs
}

Abstract

Estimates of ground-water recharge rates are fundamental to understanding and managing ground-water resources in the Suwannee River Water Management District (SRWMD). This report describes the results of four methods that were used to estimate long-term, average-annual recharge rates to the Upper Floridan aquifer, which is the primary source of freshwater for most uses in the SRWMD. Recharge rates to the Upper Floridan aquifer are controlled in large part by the degree of confinement of the aquifer. Analyses of basin water budgets and streamflow data indicated that recharge is less than 30 centimeters per year (12 inches per year) in areas where the Upper Floridan aquifer is confined by an overlying layer of sediments of low permeability. In unconfined areas, analyses of basin water budgets and streamflow, chloride, and ground-water level data indicated that recharge was probably within a range of 40 to 80 centimeters per year (16 to 31 inches per year) over most of the SRWMD. In poorly confined areas where the intermediate confining unit is leaky, recharge rates fall between the values for confined and unconfined areas.

\section{INTRODUCTION}

Ground water is a major component of the water resources in the Suwannee River Water Management District (SRWMD), accounting for all of the water withdrawals for public and self-supplied domestic water supplies and nearly all of the self-supplied commercial-industrial and agricultural irrigation withdrawals in the district (Marella, 1995). Ground water is also an important source of water for streams, lakes, and wetlands in the SRWMD. Because of this dependence on ground water, a good understanding of the ground-water system is essential to manage the surface- and ground-water resources in the SRWMD.

In 1995, the U.S. Geological Survey (USGS) began a study in cooperation with the SRWMD to estimate recharge rates to the Upper Floridan aquifer in the SRWMD. These recharge rates will provide useful information for managing the water resources in the SRWMD and are necessary for developing management tools like ground-water flow models. The purpose of this report is to describe the methods employed in the study and the results of streamflow, water-level, and water-quality analyses that were used to estimate average-annual recharge rates for the Upper Floridan aquifer. The report describes the application of four primary methods of estimating recharge to the Upper Floridan aquifer in the SRWMD: a waterbudget method, a chloride mass-balance method, analysis of ground-water discharge to rivers, and analysis of water-level changes in wells. The results of each method are compared and related to the degree of confinement of the Upper Floridan aquifer.

\section{Description of the Study Area}

The study area is the SRWMD, which is located in the northern and north-central part of peninsular Florida and covers an area of nearly 20,000 square kilometers $\left(\mathrm{km}^{2}\right)$ (fig. 1). This area lies completely within the Atlantic and Gulf Coastal Plain physiographic provinces (Fenneman, 1938). Two major physiographic divisions lie within the SRWMD: the Northern Highlands and the Gulf Coastal Lowlands (Puri and Vernon, 1964; fig. 1).

The Northern Highlands typically have gently sloping plateaus in the interior regions and marginal slopes that are well drained by dendritic streams 


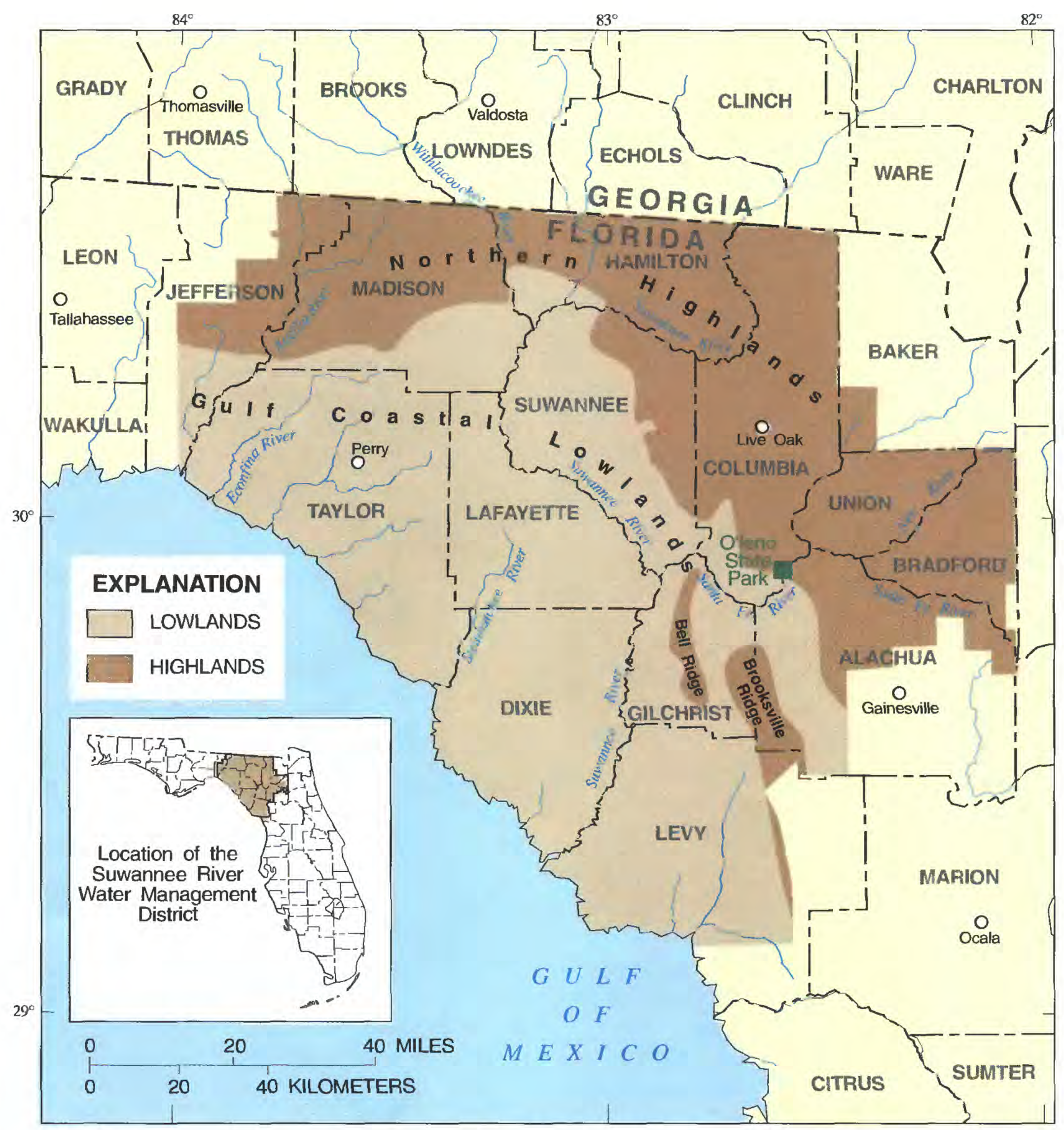

Figure 1. Location and physiographic areas of the Suwannee River Water Management District.

(Puri and Vernon, 1964). Many of these streams are captured by sinkholes near the margins of the Northern Highlands and reemerge below Cody Scarp, a prominent escarpment that separates the Northern Highlands and Gulf Coastal Lowlands (Burnson and others, 1984). A notable example of stream capture and reemergence is the Santa Fe River, which drains into a sinkhole at O'leno State Park (fig. 1) and reemerges approximately 5 kilometers $(\mathrm{km})$ southwest of the sinkhole.
The Gulf Coastal Lowlands consist of terraces and ancient shorelines that slope gently from the Northern Highlands toward the coast. Limestone occurs at or near land surface over much of this area and karst topographic features are quite common. Other features of the Gulf Coastal Lowlands include: (1) extensive areas of poorly drained swamps and flatwoods west of the Suwannee River; (2) the lower Suwannee and Santa Fe River valleys which, apart from the two main rivers and the numerous springs 
that feed them, are nearly devoid of surface drainage; and (3) coastal areas that are drained by a network of streams and coastal swamps and salt marshes.

The climate of the area is transitional temperatehumid subtropical. Temperatures typically range from 4 to 10 degrees Celsius $\left({ }^{\circ} \mathrm{C}\right)$ in the winter and from 25 to $35^{\circ} \mathrm{C}$ in the summer. Average annual precipitation ranges from 130 to 150 centimeters per year $(\mathrm{cm} / \mathrm{yr})$, with approximately one-half of this amount typically falling from June to September. Summer precipitation is generally associated with localized thunderstorm activity that can produce intense rainfall events. Winter precipitation is generally associated with the passage of cold fronts and is more evenly distributed geographically. Average-annual evapotranspiration estimates in the SRWMD range from approximately 90 to $105 \mathrm{~cm} / \mathrm{yr}$ (Bush and Johnston, 1988, pl. 9).

Three principal hydrogeologic units occur in the SRWMD: the surficial aquifer system, the intermediate confining unit, and the Floridan aquifer system. The surficial aquifer system occurs throughout the Northern Highlands area and more locally in the Gulf Coastal Lowlands. Where present, the surficial aquifer system is contiguous with land surface and consists principally of unconsolidated to poorly indurated deposits (Southeastern Geological Society Ad Hoc Committee on Florida Hydrostratigraphic Unit Definition, 1986). The intermediate confining unit lies below the surficial aquifer system and generally consists of fine-grained, unconsolidated deposits with interbedded limestone. Regionally, this unit acts as a confining unit that restricts the exchange of water between the overlying surficial and underlying Floridan aquifer systems. Permeable zones exist within the intermediate confining unit and yield water in sufficient quantities for domestic, farm, and limited irrigation uses.

The Floridan aquifer system consists of a thick sequence of carbonate rocks, and is subdivided into the Upper and Lower Floridan aquifers (Miller, 1986, p. B45). The Lower Floridan aquifer only occurs where a middle confining unit separates the more permeable Upper and Lower Floridan aquifers. In the SRWMD, the Lower Floridan aquifer is not used for water supply and only occurs in the northern part of the SRWMD from Jefferson County east to Columbia County, and in the southern half of Levy County. The Upper Floridan aquifer occurs throughout the SRWMD and is extremely permeable and capable of transmitting large volumes of water. Recharge to the Upper Floridan aquifer occurs in most of the district and is affected by the degree of confinement by the overlying intermediate confining unit (fig. 2).

Discharge from the Upper Floridan aquifer occurs as discharge to springs, streams, rivers, and coastal areas where the hydraulic head (water level) of the aquifer is above land surface. The Upper Floridan aquifer sustains the flow of the Suwannee and lower Santa Fe Rivers, as well as numerous other smaller rivers, streams, and springs in the SRWMD.

Most of the SRWMD is sparsely populated. The primary economic activities are silviculture, the manufacture of forest products, phosphate mining, and agriculture (Burnson and others, 1984). Accordingly, forest and agricultural lands account for most of the land use in the SRWMD, although wetlands also occupy a large part. In 1990, 1.3 million cubic meters per day $\left(\mathrm{m}^{3} / \mathrm{d}\right)$ of freshwater was withdrawn in the SRWMD, nearly all from the Upper Floridan aquifer (Marella, 1995). Approximately 850,000 cubic meters $\left(\mathrm{m}^{3}\right)$ of this freshwater was used for public, selfsupplied domestic, self-supplied commercialindustrial, and agricultural supplies. Thermoelectricpower generation accounted for the remaining withdrawals. Ground water accounted for approximately 97 percent of the withdrawals for public, self-supplied domestic, self-supplied commercial-industrial, and agricultural supplies.

\section{Previous Studies}

Phelps (1978) used several methods to estimate recharge in Alachua, Baker, Bradford, Clay, Columbia, and Union Counties. Although the Upper Floridan aquifer is overlain by the intermediate confining unit in this area, the unit is breached by numerous sinkholes and sinkhole lakes that act as principal paths for recharge to the aquifer (Stewart, 1980). Using a flownet or closed-contour method based on Darcy's Law. Phelps $(1978$, p. 5) computed a recharge rate of $1.64 \times 10^{5} \mathrm{~m}^{3} / \mathrm{d}$, or $4 \mathrm{~cm} / \mathrm{yr}$, near a dome in the potentiometric surface of the Upper Floridan aquifer near the junction of Alachua, Bradford, Clay, and Union Counties (Phelps, 1978, fig. 1). Recharge was about $3.42 \times 10^{5} \mathrm{~m}^{3} / \mathrm{d}(2 \mathrm{~cm} / \mathrm{yr})$ in a larger area that encompasses this dome in the potentiometric surface and parts of Columbia, Baker, Nassau, Duval, Putnam, and Marion Counties. The potentiometric surface used in this analysis was constructed from data collected in northeastern Florida during 1972. 
Using a second method based on Darcy's Law, Phelps (1978) estimated that leakage through the intermediate confining unit above the Upper Floridan aquifer ranged from 0.1 to $0.5 \mathrm{~cm} / \mathrm{yr}$. These estimates were obtained by multiplying estimates of the vertical hydraulic conductivity of the intermediate confining by the hydraulic gradient between the Upper Floridan aquifer and the permeable zones of the intermediate confining unit.
Phelps (1978) used a third method based on a water-budget analysis and estimated recharge rates of 52 to $20 \mathrm{~cm} / \mathrm{yr}$ in nine drainage basins in and adjacent to the SRWMD. Among the basins draining areas that were confined, recharge estimates ranged from -9 to $15 \mathrm{~cm} / \mathrm{yr}$. The negative rates of recharge probably result from including ground-water discharge from the Upper Floridan aquifer in the surface runoff term used in the water-budget equation (Phelps, 1978, p. 11).

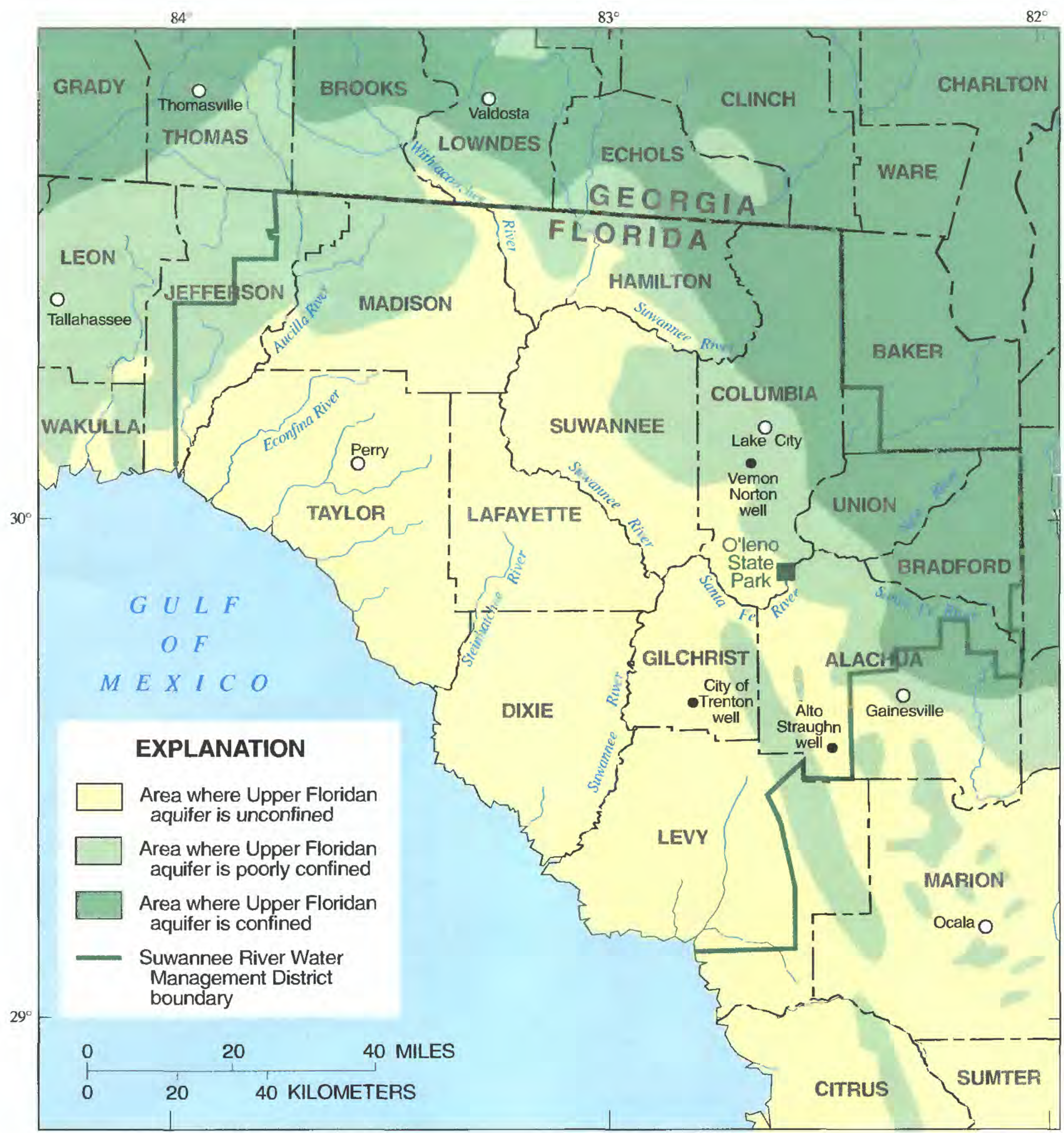

Figure 2. Confinement of the Upper Floridan aquifer in the Suwannee River Water Management District. 
The negative recharge values may also be due, in part, to uncertainties in the values of other terms in the water budget.

Clark and others (1964, p. 124) also used a closed-contour method to estimate recharge as part of an assessment of the water resources of Alachua, Bradford, Clay, and Union Counties. They estimated recharge to be greater than or equal to $5 \mathrm{~cm} / \mathrm{yr}$ near the junction of Alachua, Bradford, Clay and Union Counties, near the dome in the potentiometric surface of the Upper Floridan aquifer. Clark and others (1964) also used a water-budget approach to estimate recharge rates of at least $25 \mathrm{~cm} / \mathrm{yr}$ in western Alachua County, where the Upper Floridan aquifer is unconfined.

Stewart (1980) developed a map of recharge to the Floridan aquifer system in Florida using groundwater level, intermediate confining unit, and topographic data. The map was developed by evaluating potentiometric-surface maps of the Upper Floridan aquifer, soil drainage characteristics, the thickness and porosity of surficial sediments, the thickness and permeability of the intermediate confining unit, and topographic information. Nearly all of the SRWMD was described as having one of three categories of recharge: very low (less than $5 \mathrm{~cm} / \mathrm{yr}$ ), very low to moderate (less than 5 to $25 \mathrm{~cm} / \mathrm{yr}$ ), and high recharge ( 25 to $50 \mathrm{~cm} / \mathrm{yr}$ ). Areas of very low recharge were coincident with the Highlands area in the eastern and northeastern area of the SRWMD. Areas of very low to moderate recharge were delineated west of the Suwannee and Withlacoochee Rivers, and in coastal and central Levy County and central Gilchrist County. Areas of high recharge generally coincided with the margins of Highland areas and lowland areas adjacent to the Suwannee, lower Santa Fe, and Withlacoochee Rivers.

Bush and Johnston (1988, pl. 11) developed a map of recharge for the entire Upper Floridan aquifer based on a digital model of the Floridan aquifer system. The pattern of recharge on this map is similar to that of Stewart (1980). The highest recharge rates were approximately 40 to $50 \mathrm{~cm} / \mathrm{yr}$ and were coincident with broad areas adjacent to the Suwannee, lower Santa Fe, and Withlacoochee Rivers. The lowest recharge rates were 2.5 to $11 \mathrm{~cm} / \mathrm{yr}$, and were generally coincident with Highland areas in the northeastern and eastern area of the SRWMD and areas of central Dixie, Taylor, and Jefferson Counties. Recharge rates generally ranged from 2 to $13 \mathrm{~cm} / \mathrm{yr}$ in confined areas of the Upper Floridan aquifer, from 25 to $38 \mathrm{~cm} / \mathrm{yr}$ in poorly confined areas, and from 2 to $38 \mathrm{~cm} / \mathrm{yr}$ in unconfined areas. The lower recharge values correspond to an unconfined area near the coast, adjacent to an area of coastal discharge from the Upper Floridan aquifer. Aucott (1988) also developed a recharge map for the Floridan aquifer system that modified the map of Bush and Johnston, to a limited degree, using Stewart's (1980) approach.

Col (1994) developed a map of recharge potential for the Floridan aquifer system in the SRWMD. The map was developed by evaluating soil infiltration capacities, hydrologic basin characteristics, depth to ground water or top of the Upper Floridan aquifer, and intermediate confining unit thickness, using an approach similar to that described by Aller and others (1985). The map is a qualitative assessment of recharge (estimates of recharge rates are not presented), in which areas are classified as having a recharge potential that can range from high to low. Areas of high, moderate, and low potential are generally consistent with the maps of Stewart (1980), Aucott (1988), and Bush and Johnston (1988, pl. 11).

\section{Approach}

Four primary methods were used in this study to estimate recharge rates in the SRWMD: (1) evaluating a simple water budget for selected drainage basins; (2) using a chloride mass-balance method, (3) analyzing water-level changes in shallow wells; and (4) determining the ground-water discharge to springs or streams through analysis of stream discharge data (base-flow separation analysis). A technique known as chemical base-flow separation was also used to confirm some of the results of the base-flow separation analysis.

\section{WATER-BUDGET ANALYSIS OF SELECTED DRAINAGE BASINS}

A water-budget approach was used to estimate recharge to the Upper Floridan aquifer in two hydrologic settings found in the study area: (1) Northern Highlands areas where the Upper Floridan aquifer is confined by the intermediate confining unit, and (2) Gulf Coastal Lowlands areas of the Suwannee River and lower Santa Fe River Basins where surface runoff is generally negligible. In both settings, water budgets were developed from estimates of long-term averages of hydrologic variables (long-term average 
precipitation, evapotranspiration, and total runoff). Therefore, the water budgets reflect an assumption of long-term, dynamic equilibrium in which changes in surface and subsurface water storage are negligible when averaged over long time periods.

The first hydrologic setting to be considered was the Northern Highlands area where the Upper Floridan aquifer is generally confined by the intermediate confining unit and the surficial aquifer is present. In this setting, recharge to the Upper Floridan aquifer occurs as downward leakage from the surficial aquifer and through the intermediate confining unit (left part of fig. 3). The long-term leakage or recharge rate is equal to precipitation minus evapotranspiration, storm (direct) runoff from the land surface, and groundwater runoff from the surficial aquifer system. The sum of long-term average direct runoff and groundwater runoff equals total runoff (streamflow) from highland streams draining the surficial aquifer system. Thus, long-term recharge can be estimated as follows:

$$
R=P-E T-\left(Q_{D}+Q_{S A S}\right)=P-E T-Q_{T O T A L,}(1)
$$

where $R$ is the long-term, average recharge rate to the Upper Floridan aquifer, $P$ and $E T$ are the average precipitation and evapotranspiration rates occurring in confined areas of highland basins, respectively; $Q_{D}$ is average direct runoff from the basin from overland flow and subsurface stormflow; $Q_{S A S}$ is average ground-water runoff from the surficial aquifer system; and $Q_{\text {TOTAL }}$ is the average total runoff $\left(Q_{D}+Q_{G W}\right)$ from the basin.

Equation 1 was used to estimate recharge to the Upper Floridan aquifer in six drainage basins in the Northern Highlands where the aquifer is confined by the intermediate confining unit (table 1): Rocky Creek near Belmont (station 2, fig. 4), Deep Creek near Suwannee Valley (station 4), Robinson Creek near Suwannee Valley (station 5), Santa Fe River near Graham (station 11), New River near Lake Butler (station 12), and the Santa Fe River at Worthington Springs (station 13). Values of $Q_{\text {TOTAL }}$ in these basins were estimated with streamflow data from gaging stations operated by the USGS. Regression techniques similar to those described by Rumenik and Grubbs (1996, p. 11) were used to improve the longterm runoff estimates at stations with short-term records by developing relations with long-term stations. Precipitation and evapotranspiration values were estimated by Bush and Johnston (1988, pls. 7 and 9). Average rates of net precipitation $(P-E)$ ranged from 46 to $59 \mathrm{~cm} / \mathrm{yr}$ in these basins and total runoff ranged from 17 to $31 \mathrm{~cm} / \mathrm{yr}$ (table 1). The resulting estimates of recharge to the Upper Floridan aquifer ranged from 15 to $32 \mathrm{~cm} / \mathrm{yr}$ (table 1 ).

The second hydrologic setting that was considered is found in areas of the Gulf Coastal Lowlands where surface runoff is negligible. This setting occurs in nearly all of the Suwannee River Basin downstream from the Withlacoochee River and in the lower Santa Fe Basin (downstream from O'leno State Park) where nearly all of the basin drainage occurs through the subsurface and runoff from the surficial aquifer system is negligible. In these areas, runoff is generally negligible because very little channelized surface drainage is present, the soils are generally permeable and the slope of the land surface is generally very gradual to flat in these areas. The lowland areas also generally coincide with unconfined areas of the Upper Floridan aquifer. In this setting, long-term recharge is approximately equal to long-term net precipitation, and recharge can be estimated as follows:

$$
R=P-E T \text {. }
$$

Rates of net precipitation generally range from 43 to $58 \mathrm{~cm} / \mathrm{yr}$ over the SRWMD, which indicates that recharge over areas with negligible direct runoff and runoff from the surficial aquifer system is probably within the same range.

Recharge is probably less than the above range in lowland areas near the coast of the Gulf of Mexico, because the channelized drainage network is better developed and the water table is at or near the surface over much of the area. The latter condition favors direct runoff of rainfall through the many streams, swamps, and marshes that drain the coastal area. Additionally, recharge does not occur in much of this area where ground-water from the surficial aquifer system and Upper Floridan aquifer discharges to coastal swamps, marshes, and streams. Recharge is also probably less than the 43 to $58 \mathrm{~cm} / \mathrm{yr}$ range in the floodplain areas of the lowlands because of direct runoff occurring in these areas. 


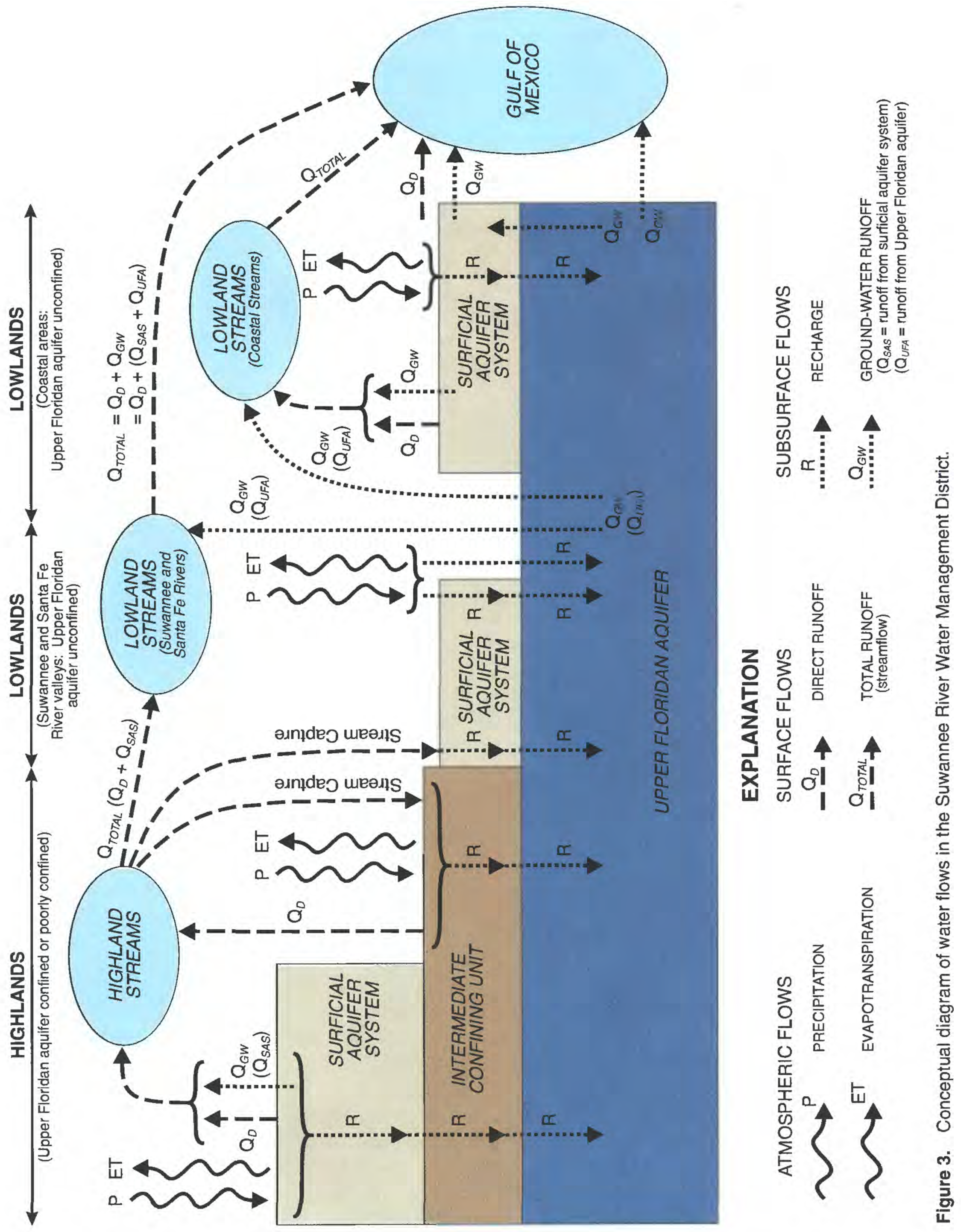


Table 1. Results of water-budget analyses of selected drainage basins

$\left[\mathrm{km}^{2}\right.$, square kilometers; $\mathrm{m}^{3} / \mathrm{s}$, cubic meters per second; $\mathrm{cm} / \mathrm{yr}$, centimeters per year, -, not applicable]

\begin{tabular}{|c|c|c|c|c|c|c|c|c|c|c|c|}
\hline \multirow{2}{*}{$\begin{array}{l}\text { Site } \\
\text { num- } \\
\text { ber } \\
\text { (see } \\
\text { fig.4) }\end{array}$} & \multirow{2}{*}{$\begin{array}{l}\text { Station } \\
\text { number }\end{array}$} & \multirow{2}{*}{ Station name } & \multirow{2}{*}{$\begin{array}{l}\text { Period of } \\
\text { record } \\
\text { anaiyzed }\end{array}$} & \multirow{2}{*}{$\begin{array}{l}\text { Drain- } \\
\text { age } \\
\text { area, } \\
\left(\mathrm{km}^{2}\right)\end{array}$} & \multirow{2}{*}{$\begin{array}{c}\text { Station } \\
\text { number } \\
\text { of index } \\
\text { station }\end{array}$} & \multicolumn{2}{|c|}{$\begin{array}{l}\text { Total annual } \\
\text { runoff }^{1}\end{array}$} & \multirow{2}{*}{$\begin{array}{l}\text { Annual } \\
\text { precipi- } \\
\text { tation, } \\
\text { (cm/yr) }\end{array}$} & \multirow{2}{*}{$\begin{array}{c}\text { Annual } \\
\text { evapo- } \\
\text { transpira- } \\
\text { tion } \\
(\mathrm{cm} / \mathrm{yr})\end{array}$} & \multirow{2}{*}{$\begin{array}{c}\text { Annual } \\
\text { precipita- } \\
\text { tion } \\
\text { minus } \\
\text { evapo- } \\
\text { transpira- } \\
\text { tion, } \\
(\mathrm{cm} / \mathrm{yr})\end{array}$} & \multirow{2}{*}{$\begin{array}{l}\text { Estimated } \\
\text { recharge } \\
\text { to the } \\
\text { Upper } \\
\text { Floridan } \\
\text { aquifer, } \\
\text { (cm/yr) }\end{array}$} \\
\hline & & & & & & $\left(\mathrm{m}^{3} / \mathrm{s}\right)$ & (cm/yr) & & & & \\
\hline 2 & 02314986 & $\begin{array}{l}\text { Rocky Creek near } \\
\text { Belmont }\end{array}$ & $1978-82$ & 129 & 02229000 & 1.3 & 31 & 137 & 91 & 46 & 15 \\
\hline 4 & 02315200 & $\begin{array}{l}\text { Deep Creek near } \\
\text { Suwannee Valley }\end{array}$ & $1978-81$ & 229 & 02229000 & 1.6 & 21 & 137 & 91 & 46 & 25 \\
\hline 5 & 02315392 & $\begin{array}{l}\text { Robinson Creek near } \\
\text { Suwannee Valley }\end{array}$ & $1976-82$ & 71 & 02229000 & 0.7 & 31 & 137 & 9l & 46 & 15 \\
\hline 11 & 02320700 & $\begin{array}{l}\text { Santa Fe River near } \\
\text { Graham }\end{array}$ & $1958-94$ & 249 & 02321500 & 1.4 & 17 & 142 & 93 & 49 & 32 \\
\hline 12 & 02321000 & $\begin{array}{l}\text { New River near Lake } \\
\text { Butler }\end{array}$ & $1951-70$ & 500 & 02321500 & 4.8 & 30 & 150 & 91 & 59 & 29 \\
\hline 13 & 02321500 & $\begin{array}{l}\text { Santa Fe River at } \\
\text { Worthington Springs }\end{array}$ & $1932-94$ & 1.489 & - & 12.4 & 26 & 143 & 93 & 50 & 24 \\
\hline
\end{tabular}

${ }^{\mathrm{I}}$ Calculated by dividing runoff, in cubic meters per second, by drainage area and converting to units of centimeters per year.

\section{CHLORIDE MASS-BALANCE ANALYSIS}

In the chloride mass-balance analysis, recharge was estimated by comparing chloride concentrations from samples of shallow ground water with rates of atmospheric deposition of chloride to the land surface. This method can be applied in areas where direct runoff is negligible and where anthropogenic sources of chloride deposition, such as fertilizers, are negligible or can be estimated with acceptable accuracy. Examples of studies in which this method has been applied can be found in Vacher and Ayers (1980). Grubbs (1995a), and Lee (1996).

The chloride mass-balance method is based on a simple conceptual model of chloride transport from the land surface to the water table. Chloride is deposited on the land surface in two forms: wet (dissolved in precipitation) and dry (marine aerosol or particulate) deposition. In areas where direct runoff is negligible, the mass flux of chloride ions across the water table ( $M_{R}$, expressed in units of chloride mass per unit area per unit time) is equal to the total (wet plus dry) deposition rate of chloride to the land surface $\left(M_{A}\right)$. This last sentence may be expressed as:

$$
M_{R}=M_{A}=M_{w e t}+M_{d r y}
$$

where $M_{w e t}$ and $M_{d r y}$ are the wet and dry deposition rates of chloride, respectively. The conservation of chloride mass implied by equation 3 arises because losses of chloride to the atmosphere by evaporation and transpiration are negligible. In addition, long-term changes in the amount of chloride stored in plants and in the vadose zone can also be reasonably assumed to be negligible in the study area.

The average chloride concentration in recharge, $\left[\mathrm{Cl}_{R}\right]_{R}$, is equal to the mass flux of chloride at the water table, $M_{R}$, divided by the recharge rate, $R$ (expressed in units of volume per unit area per unit time, or equivalently in units of length per unit time), because the chloride from atmospheric deposition is dissolved and transported in the water recharging the aquifer:

$$
\left[\mathrm{Cl}^{-}\right]_{R}=\mathrm{M}_{\mathrm{R}} / \mathrm{R}
$$


Additionally, the average chloride concentration in ground water, $\left[\mathrm{Cl}^{-}\right]_{G W}$, in recharge areas should be equal to the average chloride concentration in recharge:

$$
\left[\mathrm{Cl}^{-}\right]_{G W}=\left[\mathrm{Cl}^{-}\right]_{R}
$$

Substituting equation 4 into equation 5 yields the following equation:

$$
\left[\mathrm{Cl}^{-}\right]_{G W}=M_{R} / R
$$

Substituting equation 3 into equation 6 yields:

$$
\left[C l^{-}\right]_{G W}=M_{A} / R=\left(M_{w e t}+M_{d r y}\right) / R,
$$

which can be rearranged to yield an expression for recharge:

$R=M_{A} /\left[\mathrm{Cl}^{-}\right]_{G W}=\left(M_{w e t}+M_{d r y}\right) /\left[C l^{-}\right]_{G W .}{ }^{(8)}$

In some studies, recharge is computed using an equivalent form of equation 8 :

$$
R=P *\left[\mathrm{Cl}^{-}\right]_{A} /\left[\mathrm{Cl}^{-}\right]_{G W},
$$

where $P$ is the average precipitation rate, and $\left[\mathrm{Cl}^{-}\right]_{A}$ is the hypothetical chloride concentration that would result from dissolving the wet and dry atmospheric chloride deposition into the average volume of precipitation that falls over a unit area of the land surface.

Equation 8 indicates that an average recharge rate can be estimated if the total atmospheric deposition rate of chloride and the average chloride concentration in ground water are known. The total atmospheric deposition rate of chloride is typically estimated using two methods: (1) measuring the chloride concentration of samples from bulk (wet plus dry) deposition collectors, multiplying this concentration by the sample volume or precipitation volume (the product of precipitation and sampler collection area) during the sampling period, and dividing by the length of the sampling period; or (2) measuring the chloride concentration of samples from wet-deposition collectors, multiplying this concentration by the sample or precipitation volume, and by the expected ratio of total deposition to wet deposition (determined from studies of wet and dry deposition), and dividing by the length of the sampling period. When the second approach is used, a precipitation-weighted average concentration is often determined from multiple wet-deposition samples (collected, for example, over the course of a year) before multiplying by the ratio of total deposition to dry deposition.

\section{Chloride Concentrations in Ground Water}

Ideally, recharge should be determined by measuring the chloride concentration of water in the vadose zone just above the water table. However, vadose-zone water-quality data are generally very limited and difficult to collect. Accordingly, chloride concentrations of recharge waters were estimated in this study from samples of ground water taken below the water table. These data were obtained from the Background Network of wells that are part of the Florida Ground Water Quality Monitoring Network (Maddox and others, 1992), which is managed by the Florida Department of Environmental Protection. The purpose of the network is to define background water quality in the major aquifer systems in Florida. Data used in the analysis were limited to samples from wells which were drilled in unconfined areas of the Upper Floridan aquifer.

The geographic distribution of wells and associated chloride concentrations is shown in figure 5. The median chloride concentration in these wells was 6.2 milligrams per liter $(\mathrm{mg} / \mathrm{L})$, and the 25 th and 75 th percentiles were 4.4 and $9.2 \mathrm{mg} / \mathrm{L}$, respectively. With the exception of the higher chloride concentrations occurring adjacent to the Gulf of Mexico coastline, no obvious geographic patterns of chloride concentrations were evident (fig. 5).

\section{Rates of Atmospheric Deposition of Chloride}

Rates of atmospheric deposition of chloride were obtained from previous data collections and investigations, and from data collected during this study (fig. 6, table 2). Historic chloride deposition data were available from a number of stations in and near the study area. All of these stations were in inland locations. Irwin and Kirkland (1980) reported average chloride concentrations of 0.9 to $1.2 \mathrm{mg} / \mathrm{L}$ from bulk (wet plus dry) deposition samples collected in Ocala (fig. 6, station 22) and Palatka (approximately $70 \mathrm{~km}$ east of Gainesville), which correspond to averageannual bulk-deposition rates of 1.2 and 1.6 grams per square meter per year $\left(\left(\mathrm{g} / \mathrm{m}^{2}\right) / \mathrm{yr}\right)$, respectively 
(obtained by using the normal annual rainfall rate of $131 \mathrm{~cm} / \mathrm{yr}$ at Ocala. Wet deposition samples were also collected at the Ocala station and had an average concentration of $0.3 \mathrm{mg} / \mathrm{L}$ (Irwin and Kirkland, 1980), which is three times smaller than the value from the bulk sample. Hendry and Brezonik (1980) reported volume weighted mean concentrations of chloride of 0.98 and $1.88 \mathrm{mg} / \mathrm{L}$ in samples of wet and bulk deposition, respectively, collected at Gainesville, during
1976-77 (station 18). Deposition rates for this same period were 1.18 and $2.27\left(\mathrm{~g} / \mathrm{m}^{2}\right) / \mathrm{yr}$ for wet and bulk deposition, respectively. Baker and others (1986) estimated bulk chloride deposition rates ranging from 0.92 to $1.1\left(\mathrm{~g} / \mathrm{m}^{2}\right) / \mathrm{yr}$ at McCloud Lake (station 21), about 40 kilometers east of Gainesville. A wetdeposition rate of $0.92\left(\mathrm{~g} / \mathrm{m}^{2}\right) / \mathrm{yr}$ (data from Joseph Bernert, written commun., 1992) occurred during 1989-90 at Lake Barco (station 20), about $25 \mathrm{~km}$ east

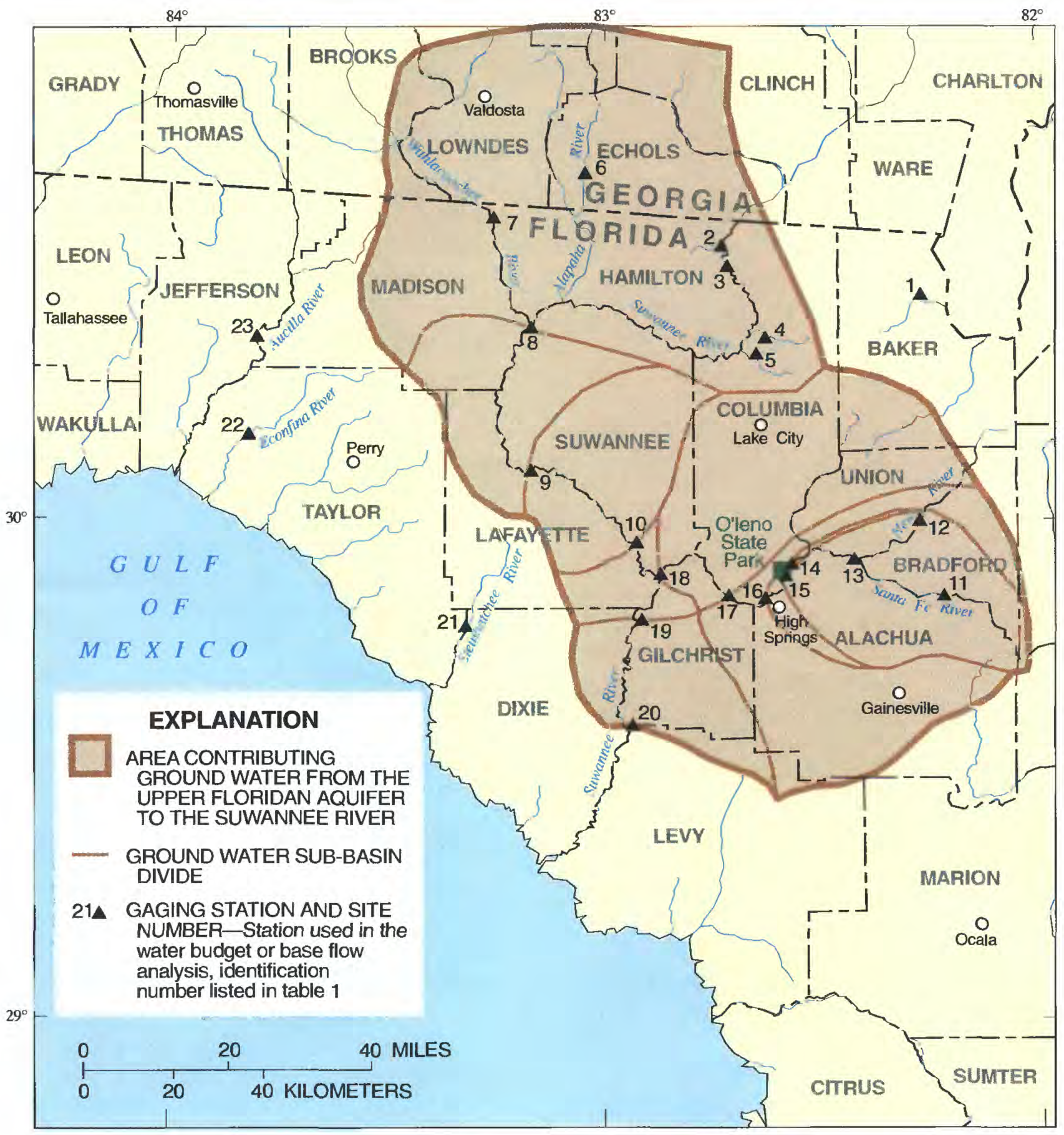

Figure 4. Locations of gaging stations used in the water budget or base flow analyses. 


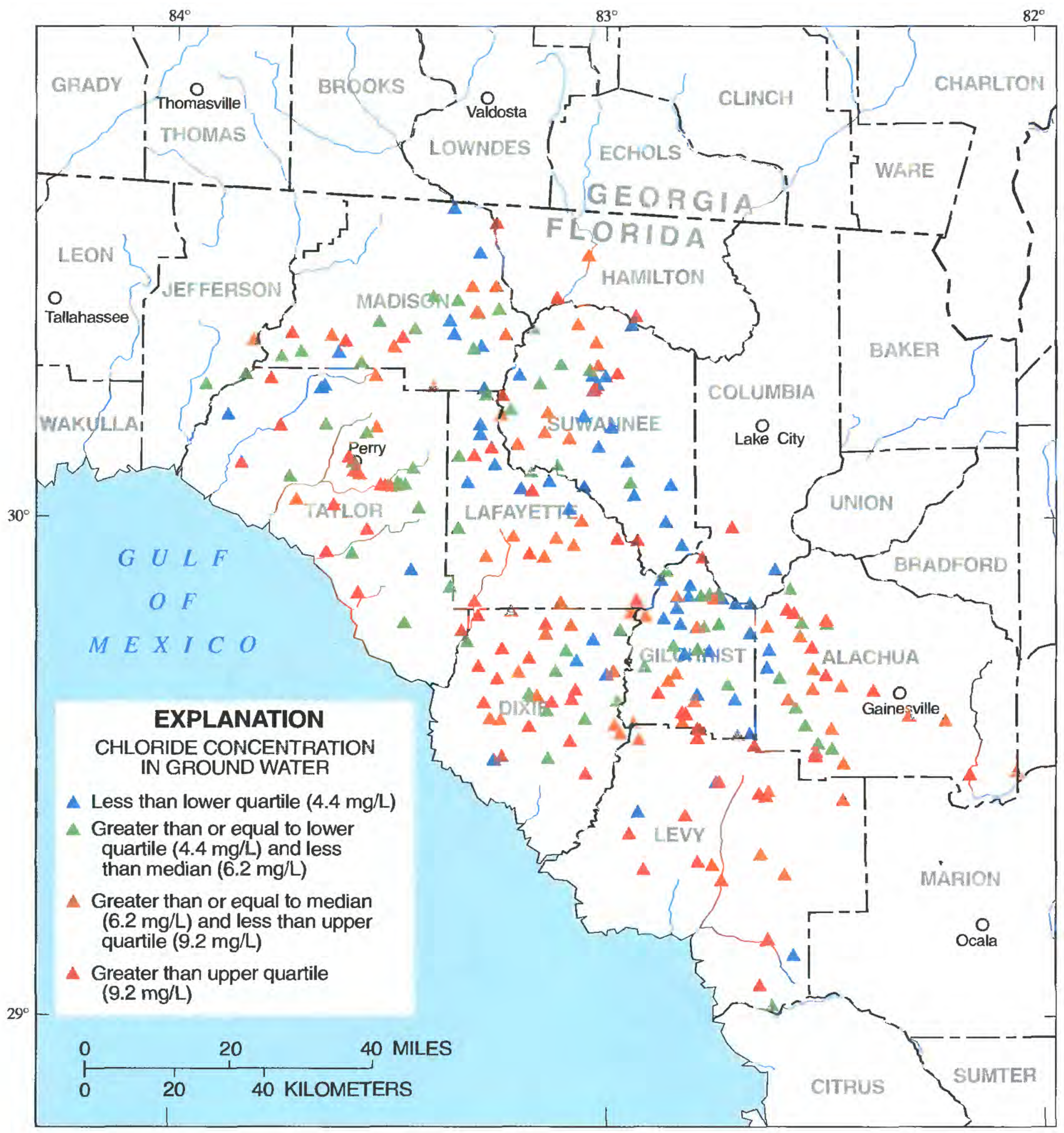

Figure 5. Chloride concentrations in ground water in the Suwannee River Water Management District.

of Gainesville. Applying Baker's (1991) dry-deposition to wet-deposition ratio for chloride $(0.42)$ results in a chloride bulk deposition rate of $1.3\left(\mathrm{~g} / \mathrm{m}^{2}\right) / \mathrm{yr}$ at Lake Barco during this period.

Long-term data were available from the Florida Atmospheric Deposition Study (Environmental Science and Engineering, Inc., 1987) and the National Atmospheric Deposition Network/National Trends Network (NADPN/NTN) (NADPN/NTN, electronic commun., 1997). Average-annual wet deposition rates of 0.77 and $0.64\left(\mathrm{~g} / \mathrm{m}^{2}\right) / \mathrm{yr}$ were observed at stations in Monticello (station 1) and Gainesville (station 19), respectively, that were part of the Florida Atmospheric Deposition Study (FADS) from 1982 to 1986 (Pollman and Canfield, 1991). Pollman and Canfield (1991) also reported bulk deposition rates of 0.97 and 0.95 $\left(\mathrm{g} / \mathrm{m}^{2}\right) / \mathrm{yr}$ for the Monticello and Gainesville stations, respectively. Average annual wet deposition rates of $0.66\left(\mathrm{~g} / \mathrm{m}^{2}\right) / \mathrm{yr}$ were observed 


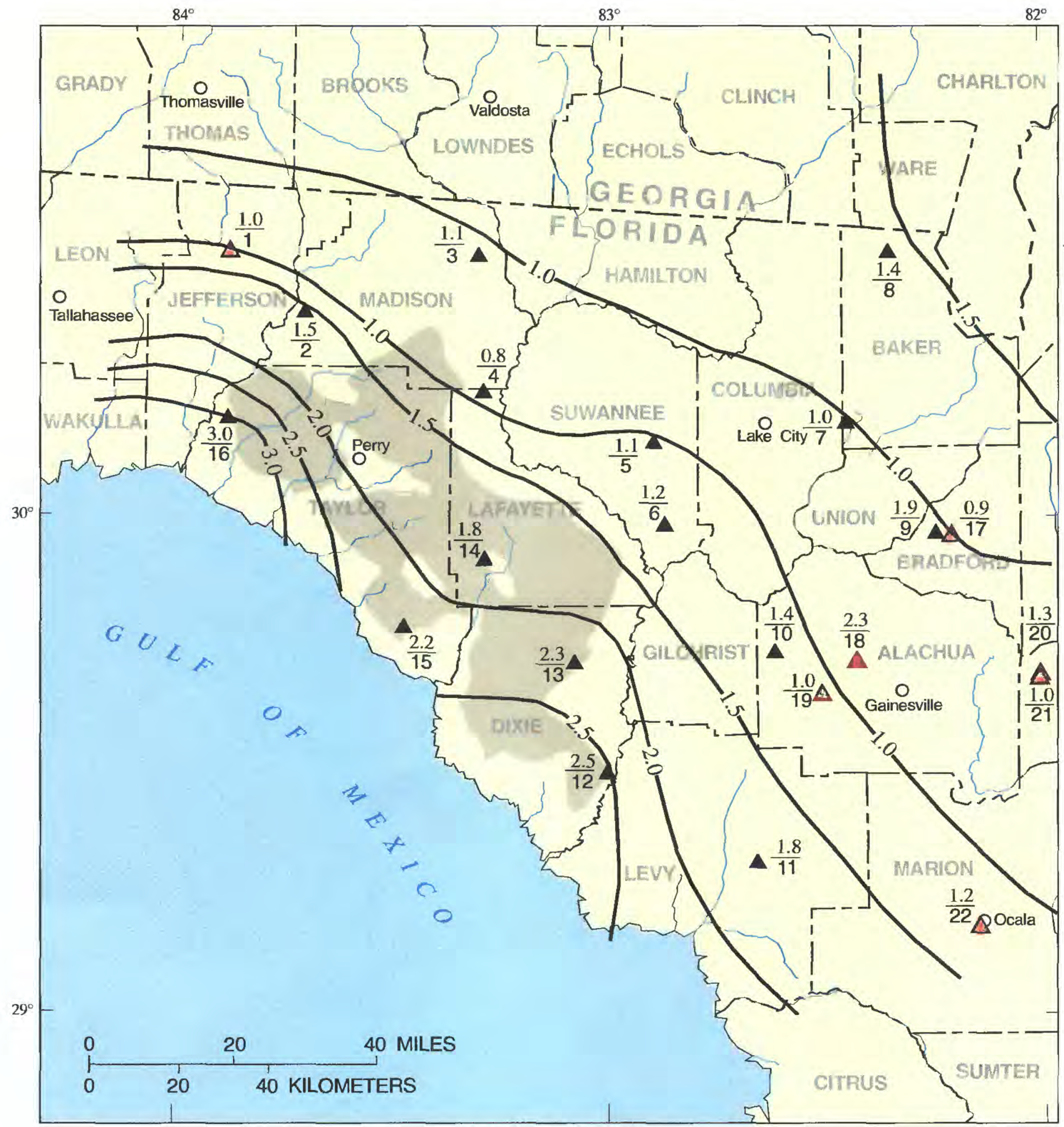

EXPLANATION

AREA OF LOW INTENSITY LAND USE

-1.5- ESTIMATED LINE OF EQUAL VALUE OF ATMOSPHERIC DEPOSITION OF CHLORIDE-in grams per square meter

$\Delta \frac{1.8}{11}$ STATION ESTABLISHED IN THIS STUDY - Top number is the estimated or measured bulk atmospheric deposition rate of chloride, in grams per square meter per year. Bottom number is the statiorı ideritifier

$A \frac{1.2}{22}$ STATION FROM PREVIOUS STUDY - Top number is the estimated or measured bulk atmospheric depositiorı rate of chloride, ir grams per square meter per year. Bottom riumber is the station identifier

Figure 6. Atmospheric deposition rates of chloride irı the Suwarırıee River Water Managemert District. 
Table 2. Atmospheric deposition in or near the Suwannee River Water Management District

[FADS, Florida Acidic Deposition Network; DOF, Florida Division of Forestry; USFS, U.S. Forest Service; NADP/NTN, National Atmospheric Deposition Network/National Trends Network; USGS, U.S. Geological Survey; $\left(\mathrm{g} / \mathrm{m}^{2}\right) / \mathrm{yr}$, grams per square meter per year]

\begin{tabular}{|c|c|c|c|}
\hline $\begin{array}{l}\text { Station } \\
\text { number }\end{array}$ & Station name & Period of record & $\begin{array}{l}\text { Buik deposi- } \\
\text { tion rate, } \\
\left(\mathrm{g} / \mathrm{m}^{2}\right) / \mathrm{yr}\end{array}$ \\
\hline 1 & FADS - Monticello Station & $1982-86$ & 0.97 \\
\hline 2 & DOF - Aucilla Fire Tower & March 1996-February 1997 & 1.50 \\
\hline 3 & DOF - Gibson Fire Tower & March 1996-February 1997 & 1.09 \\
\hline 4 & DOF - Mill Creek Fire Tower & March 1996-February 1997 & 0.83 \\
\hline 5 & DOF - Rocky Hill Fire Tower & March 1996-February 1997 & 1.08 \\
\hline 6 & DOF - Beachville Fire Tower & March 1996-February 1997 & 1.22 \\
\hline 7 & USFS-Olustee Center & March 1996-February 1997 & 0.97 \\
\hline 8 & DOF - Eddy Fire Tower & March 1996-February 1997 & 1.44 \\
\hline 9 & DOF - Starke Work Center & March 1996-February i997 & 1.89 \\
\hline 10 & DOF - Forest Grove Fire Tower & March 1996-February 1997 & 1.35 \\
\hline 11 & DOF - Wekiva Fire Tower & March 1996-February 1997 & 1.81 \\
\hline 12 & DOF - Sunnyvale Fire Tower & March 1996-February 1997 & 2.54 \\
\hline 13 & DOF - Holly Hill Fire Tower & March 1996-February 1997 & 2.30 \\
\hline 14 & DOF - Cooks Hammock Fire Tower & March 1996-February 1997 & 1.83 \\
\hline 15 & DOF - Salem Fire Tower & March 1996-February 1997 & 2.22 \\
\hline 16 & DOF - Cabbage Grove Fire Tower & March 1996-February 1997 & 2.96 \\
\hline 17 & NADPN/NTN - Bradford Forest Station & March 1996-February 1997 & 0.94 \\
\hline 18 & Hendry and Brezonik (1981) Station & June 1976-July 1977 & 2.27 \\
\hline 19 & FADS - Gainesville Station & $1982-96$ & 0.95 \\
\hline 20 & USGS - Lake Barco & July 1989-January 1991 & 1.3 \\
\hline 21 & McCloud Lake & September 1981-August 1982 & $0.92-1.1$ \\
\hline 22 & Federal Building, Ocala & 1965 & 1.2 \\
\hline- & Buckman Lock near Palatka & January-November 1975 & 1.6 \\
\hline- & NADP/NTN Quincy & $1984-95$ & 0.94 \\
\hline
\end{tabular}

at two NADPN/NTN stations in the Bradford Forest near Starke (station 17, during 1979-95), and near Quincy (during 1984-95), about $30 \mathrm{~km}$ northwest of Tallahassee. A bulk deposition rate of $0.94\left(\mathrm{~g} / \mathrm{m}^{2}\right) / \mathrm{yr}$ can be computed from these wet-deposition rates by applying Baker's (1991) dry-wet deposition ratio of 0.42 .

These historic data were supplemented with samples collected during the study at 15 locations in and around the SRWMD (fig. 6, table 2). This was done to better understand geographic differences in deposition rates and to obtain deposition rates during the study for comparison with the historical data. All of these stations were equipped with a simple bulk deposition collector, which consisted of a funnel connected with polyethylene tubing to a sample collection bottle. A loop was formed in the tubing to minimize loss of sample to evaporation, and a saw-toothed pattern was cut into the funnel lip to minimize sample contamination from bird excrement (from roosting birds). One of the stations, Rocky Hill Fire Tower (station 5), was also equipped with an Aerochemetrics wet-dry collector.

Results of the deposition analyses at the 15 supplemental stations are illustrated in figure 6 , along with results from other studies previously mentioned. Data from the supplemental stations indicate that bulk chloride deposition rates were generally highest for the stations closest to the Gulf of Mexico (stations 11 through 16). Deposition rates for these supplemental stations ranged from 1.8 to $3.0\left(\mathrm{~g} / \mathrm{m}^{2}\right) / \mathrm{yr}$. Bulk deposition rates were generally lower $\left(0.8-1.5\left(\mathrm{~g} / \mathrm{m}^{2}\right) / \mathrm{yr}\right)$ for supplemental stations further inland (stations 2 through 8 and station 10). An exception was station 9 , which had a higher bulk deposition rate of $1.9\left(\mathrm{~g} / \mathrm{m}^{2}\right) / \mathrm{yr}$. The range of deposition rates observed at the supplemental stations in inland areas is similar to the range in the data from the historic stations described previously. 


\section{Comparison of Atmospheric Deposition of Chloride with Chloride Concentrations in Ground Water}

The maps of atmospheric deposition of chloride (fig. 6) and chloride concentrations in ground water from wells in the unconfined areas of the Upper Floridan aquifer (fig. 5) were used to estimate recharge by applying equation 8 . The median recharge rate from this analysis was $24 \mathrm{~cm} / \mathrm{yr}$, and the 25 th and 75 th percentile were 14 and $35 \mathrm{~cm} / \mathrm{yr}$, respectively (table 3).

Table 3. Recharge estimates from chloride mass-balance analysis

\begin{tabular}{lcc}
\hline Statistic & $\begin{array}{c}\text { Recharge rate in unconfined areas of } \\
\text { the Upper Fioridan aquifer, } \\
\text { in centimeters per year }\end{array}$ \\
\cline { 2 - 3 } & $\begin{array}{c}\text { All unconfined } \\
\text { areas }\end{array}$ & $\begin{array}{c}\text { Low-intensity } \\
\text { iand use area } \\
\text { only (see figure 6) }\end{array}$ \\
\hline $\begin{array}{l}\text { Number of } \\
\text { observations }\end{array}$ & 309 & 57 \\
Mean & 27 & 29 \\
95th percentile & 58 & 54 \\
75 th percentile & 35 & 37 \\
Median & 24 & 27 \\
25th percentile & 14 & 21 \\
5th percentile & 5 & 7 \\
\hline
\end{tabular}

Wells located in areas near the Gulf of Mexico coast with land-surface elevations less than 5 meters were excluded from this analysis to avoid ground-water data in which the chloride concentrations could have been affected by coastal flooding (storm surge) of saline water from the Gulf of Mexico. The geographic distribution of recharge estimates from the above analysis is shown in figure 7. Distinct geographic patterns of recharge were difficult to discern from figure 7. However, estimated recharge rates were generally greater than the median in Dixie and Gilchrist Counties, and lower than the median in Alachua County.

The estimated recharge rates from the above analysis were significantly lower than the expected rates of $45-50 \mathrm{~cm} / \mathrm{yr}$ that were estimated from the water-budget analysis. Several possible explanations can account for this discrepancy. First, the deposition rates that were used in the analysis do not include deposition of chloride from fertilizers. Chloride is commonly present in fertilizers in the form of potassium chloride and is often applied at rates of 5 to 40 times that of atmospheric deposition. Fertilizer applications will result in higher than expected chloride concentrations in ground water (and therefore lower than expected estimates of recharge) and might also result in erroneous inferences about geographic patterns of recharge. For example, the recharge rates estimated in Alachua County may underestimate actual rates, because agricultural activities in this area might have increased the chloride concentration in ground water.

To eliminate possible effects of agricultural activities on the recharge estimates, the analysis was restricted only to include wells located in swampy and flatwoods areas in parts of Taylor, Lafayette, Dixie, Gilchrist, and Levy Counties (delineated as the low intensity land-use area in fig. 6). The land use in these areas is generally limited to pine tree cultivation, other upland forests, or wetlands. Applications of potassium fertilizers (including potassium chloride) are unlikely to occur in the areas of pine tree cultivation (Alan Long, University of Florida School of Forest Resources and Conservation, oral commun., 1997), other upland forests or wetlands. The median, 25th and 75 th percentile estimates of recharge from this analysis were 27,21 , and $37 \mathrm{~cm} / \mathrm{yr}$, respectively (table 3 ). These estimates are only marginally higher than estimates from the analysis that included all land use classes and other unconfined areas of the SRWMD. This suggests that some factor other than fertilizer applications can be responsible for recharge estimates (using the chloride mass-balance method) that were lower than those from the water-budget analysis.

Uncertainty in the estimates of atmospheric deposition of chloride is another possible explanation for lower than expected recharge rates from the massbalance analysis. Year-to-year variation (temporal variations) in chloride deposition is one source of uncertainty. Annual wet-deposition rates of chloride at the long-term NADPN/NTN stations near Quincy and in the Bradford Forest typically varied by $15-20$ percent from annual mean deposition rates, and the largest differences were 40 percent or less. Measurement error (reproducibility variation) is a second source of uncertainty. Nilles and others (1994) compared differences in wet deposition collected from collocated samplers from the NADPN/NTN. Median differences in chloride deposition at individual study stations ranged from 8 to 20 percent. A third source of uncertainty occurs when estimating bulk deposition from wet deposition measurements. The coefficient of variation 
for the ratio between dry deposition and wet deposition for FADS stations in Florida (Baker, 1991) was 33 percent (the standard deviation of the ratio $(0.14)$ divided by the mean ratio ( 0.42 ) equals 0.33 ). Given the range of wet deposition data previously described $\left(0.3-1.2\left(\mathrm{~g} / \mathrm{m}^{2}\right) / \mathrm{yr}\right.$, with most stations falling within $0.6-0.9\left(\mathrm{~g} / \mathrm{m}^{2}\right) / \mathrm{yr}$ ), this source of uncertainty (in calculating bulk deposition rates of chloride) is within a range of 8 to 33 percent and, more typically, within a range of 11 to 16 percent. These results are consistent with data obtained in this study from a wet deposition collector collocated with the bulk deposition collector at station 5 (fig. 6, Rocky Hill Fire Tower). The difference between the bulk deposition measured in the bulk collector and that estimated from the wet collector (using Baker's (1991) ratio of dry-deposition to wetdeposition ratio) was 12 percent. Another source of error is sample contamination. This source of error can

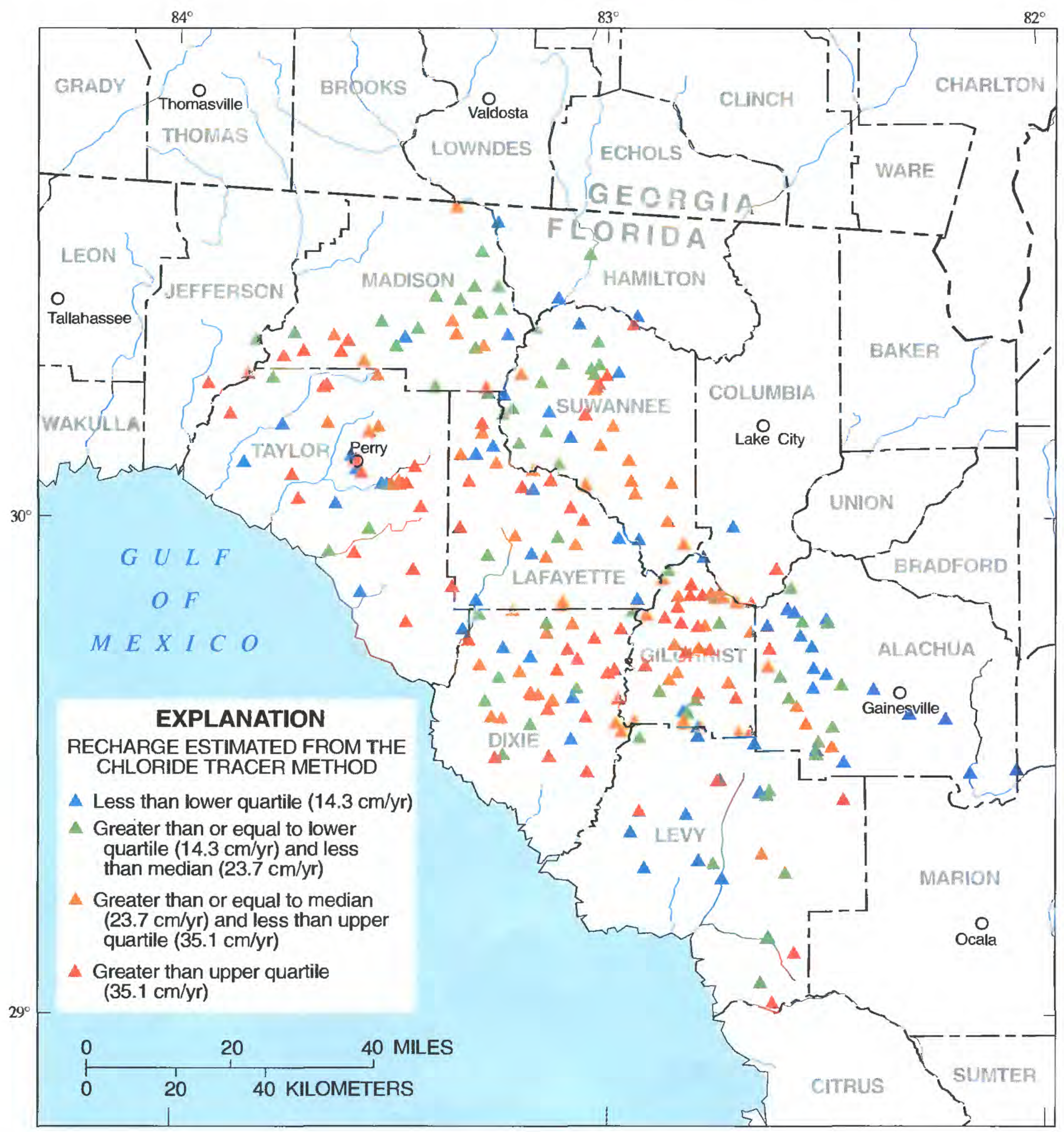

Figure 7. Recharge rates computed from chloride concentrations in ground water and atmospheric deposition rates of chloride. 
partly explain the relatively high estimates of deposition rates observed at stations 9 and 18 . The former station is located adjacent to a highway and data from the latter station indicated that nonmarine sources of chloride might have been measured in the sample. These stations were given little weight in developing the contour lines in figure 6. Also, there was also no evidence of sample contamination in the data used to estimate bulk deposition at the other stations. Thus, it is unlikely that sample contamination can account for lower than expected recharge estimates from the chloride mass-balance analysis (relative to the estimates from the water-budget analysis). The combined uncertainty due to the other sources of uncertainty (temporal and spatial variability and the ratio of dry deposition to wet deposition) is probably less than 50 percent. Therefore, it is unlikely that the above sources of uncertainty can fully account for the apparently low (relative to the water-budget analysis) recharge estimates from the chloride mass-balance analysis, because the estimates from the water-budget analysis are approximately 70-100 percent higher than the median estimates from the chloride mass-balance analysis.

Another explanation for the lower than expected values is that chloride concentrations in ground water might be higher than normal because rainfall (and therefore recharge) has been lower than expected during the recent past. Conditions have been dryer than normal in the study area since the early 1970's, based on long-term data collected at Gainesville. Distinct dry periods occurred during 1985, 1989, and 1990 throughout most of the study area. The difference between runoff measured in the Suwannee River near Wilcox (site 20) (which captures much of the drainage from the study area) during these years and long-term, average-annual runoff is similar to the difference between recharge rates estimated using the chloride mass-balance method and rates expected from the water-budget analysis. However, the remaining years since 1985 have been more typical. In addition, significantly wetter than normal conditions occurred during 1987 and 1991. Thus, it is unlikely that recharge estimates from the chloride mass-balance method are lower than expected solely because climatic conditions have been dryer than normal in the recent past.

A final explanation for the lower than expected values of recharge is that chloride concentrations in ground water can be affected by the transport of older, more mineralized water. Insufficient data make it difficult to assess whether this explanation is plausible. Estimates of travel times of water in the Upper Floridan aquifer (based on observed head gradients, flow path lengths, and estimated hydraulic property values) are imprecise but do indicate that some ground water in the SRWMD could be of Pleistocene age, which is the last time that sea level was high enough to encroach on peninsular Florida. However, two factors indicate that older water cannot account completely for the low recharge estimates. First, most of the ground-water samples that were used in this study were from relatively shallow wells (less than $33 \mathrm{~m}$ deep) and ground-water ages typically increase with depth in unconfined areas of the Upper Floridan aquifer. Second, recent analyses of tritium and chlorofluorocarbons in springs and shallow ground-water wells (less than $33 \mathrm{~m}$ ) in the middle Suwannee and lower Santa Fe River Basins indicate that spring and shallow ground-water samples are from relatively young ground water, generally less than 30 years old (Brian Katz, U.S. Geological Survey, written commun., 1997). Thus, it is uncertain whether older water accounts for the lower than expected recharge estimates. It is plausible that this explanation or a combination of the possible explanations described above may account for the difference between the chloride mass-balance estimates of recharge and the expected rates based on the water-budget analysis.

Despite the questionable results of the chloride mass-balance method in this study, the method has been applied successfully within the study area in another investigation. As part of a study of the hydrology of a sinkhole lake east of Gainesville, Lee (1996) used on-site measurements of wet deposition of chloride, Baker's (1991) ratio of dry-deposition to wetdeposition for chloride, and on-site measurements of chloride concentrations in the surficial aquifer system to estimate recharge. The results were subsequently used to model ground-water flow adjacent to Lake Barco and to develop a water budget for the lake, using simulated flows from the model, lake evaporation estimates, and precipitation observations. Lee's (1996) chloride mass-balance results indicated that 29 percent $(39 \mathrm{~cm} / \mathrm{yr})$ of long-term precipitation $(134 \mathrm{~cm} / \mathrm{yr})$ recharged the surficial aquifer system, and the remaining 71 percent $(95 \mathrm{~cm} / \mathrm{yr}$ ) was lost to evapotranspiration from the land surface (surface runoff is negligible in the Lake Barco area). Most of the recharge to the surficial aquifer system in the Lake Barco watershed ultimately leaks downward to the 
Upper Floridan aquifer through breaches in the intermediate confining unit.

Several inferences can be drawn from the Lake Barco results. First, the land-surface evapotranspiration rate that was estimated for the Lake Barco watershed $(95 \mathrm{~cm} / \mathrm{yr})$ by Lee (1996) is consistent with the 97-cm/yr evapotranspiration rate of Bush and Johnston (1988, pl. 9) for this area. This supports the assumption that Bush and Johnston's estimates of evapotranspiration are reasonably accurate values for the SRWMD. Second, Lee's (1996) estimate of recharge to the surficial aquifer system $(39 \mathrm{~cm} / \mathrm{yr})$ is comparable to Bush and Johnston's (1988, pl. 7 and 9) estimate of net precipitation (and therefore surficial aquifer system recharge) for the Lake Barco area $(46 \mathrm{~cm} / \mathrm{yr})$. This supports the assumption that recharge to the Upper Floridan aquifer is approximately equal to net precipitation estimates obtained from plates 7 and 9 of Bush and Johnston (1988) in unconfined areas, where surface drainage is negligible. In areas with a high density of lakes, such as the Lake Barco area, recharge to the Upper Floridan aquifer will be somewhat less than recharge to the surficial aquifer system. This is because lake evaporation exceeds land-surface evapotranspiration. Lakes cover approximately 20 percent of the land area in the Lake Barco area, so recharge to the Upper Floridan aquifer is probably closer to $33 \mathrm{~cm} / \mathrm{yr}$, based on an area-weighted average of lake evaporation and land-surface evapotranspiration (a comparable, but slightly higher value of $38 \mathrm{~cm} / \mathrm{yr}$ is obtained if Bush and Johnston's (1988) precipitation and evapotranspiration rates are used instead of Lee's (1996)). Typically, lakes cover less than a few percent of the land area of the SRWMD, so net-precipitation should be a good approximation of recharge in unconfined areas of the Upper Floridan aquifer that lack surface drainage. As described previously (in the water-budget method section), this suggests that ground-water recharge in unconfined areas will fall within a range of approximately $45-60 \mathrm{~cm} / \mathrm{yr}$ in the SRWMD. Finally, the Lake Barco results also provide useful information for estimating recharge to the Upper Floridan aquifer in poorly confined areas, because Lake Barco occurs in such an area. In poorly confined areas where surface drainage is absent, the results suggest that recharge to the Upper Floridan aquifer will be approximately equal to net precipitation. Recharge rates in poorly confined areas will be less than net precipitation where lake densities are high or where surface drainage carries direct runoff and ground-water runoff from the surficial aquifer system. This suggests that recharge rates in poorly confined areas will fall within the ranges defined by the water-budget analyses of confined and unconfined areas.

\section{ANALYSIS OF GROUND-WATER DISCHARGE TO STREAMS}

Recharge rates in the SRWMD were estimated by evaluating ground-water discharge to streams using two approaches: hydrometric base-flow separation and chemical base-flow separation. The hydrometric method was used to estimate long-term recharge rates in the SRWMD, while the chemical method was useful for checking the results of the hydrometric method.

\section{Hydrometric Base-Flow Separation}

A base-flow separation technique (Rutledge, 1991, p. 33-40) was used to estimate average groundwater runoff at unregulated gaging stations in the SRWMD with continuous (daily) streamflow data. When averaged over long periods of time, changes in the volume of water stored in the Upper Floridan aquifer are negligible compared to annual ground-water discharge to streams. Thus, over long periods, the average ground-water discharge rate to a given stream (ground-water runoff) is approximately equal to the average recharge rate occurring over the contributing area to that stream. This last statement is the basis for estimating long-term average recharge rates using base-flow separation methods. These recharge rates can be expressed as the volume of water recharging a unit area of aquifer per unit of time or, equivalently, as a depth of water per unit time. This is accomplished by dividing the average annual ground-water runoff (expressed as a volume per unit time) by the area that contributes ground water to the stream and converting to the appropriate units of length per unit time. Topographic and potentiometric-surface maps are used to define these contributing areas.

Base-flow separation analyses are typically done at stations with long periods of continuous discharge records. However, these results can also be used to estimate ground-water runoff in streams with limited discharge data (partial-record stations). This is accomplished by correlating discharge measurements at partial record stations with concurrent streamflows at nearby gaging stations that have long-term, 
Table 4. Total runoff and ground-water runoff at individual streamflow stations

$\left[\mathrm{km}^{2}\right.$, square kilometers; $\mathrm{m}^{3} / \mathrm{s}$, cubic meters per second; $\mathrm{cm} / \mathrm{yr}$, centimeters per year; --, not applicable. All sites are in Florida unless otherwise noted]

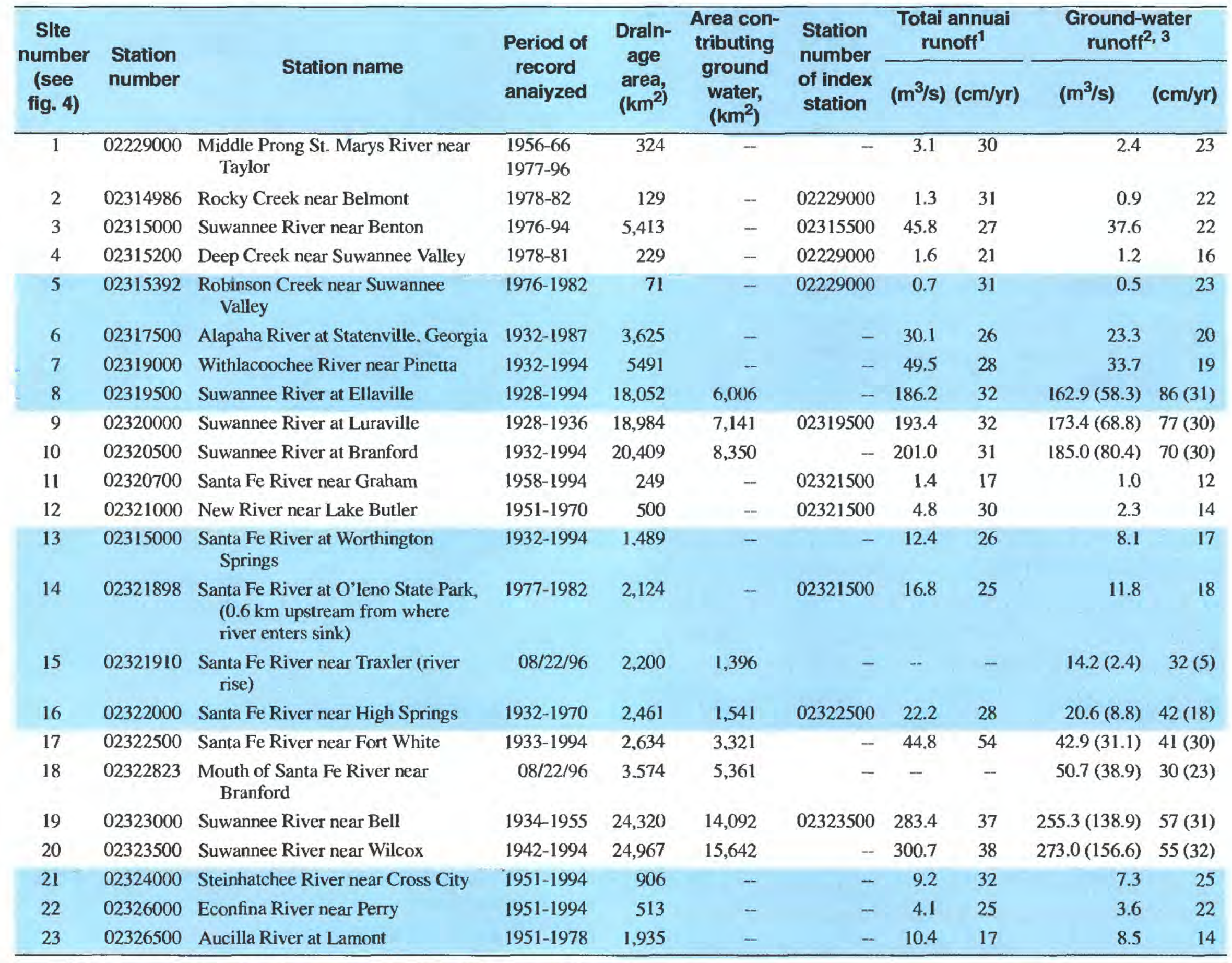

${ }^{1}$ Values reported in $\mathrm{cm} / \mathrm{yr}$ units were calculated by dividing runoff by drainage area.

${ }^{2}$ Values reported in $\mathrm{cm} / \mathrm{yr}$ units were calculated by dividing runoff by area contributing ground water.

${ }^{3}$ Values in parentheses reflect corrections for ground-water runoff contributions from the surficial aquifer system.

continuous daily discharge data (Vecchioli and others, 1990; Grubbs, 1995b). Estimates of average-annual ground-water runoff can also be made by measuring discharge at streamflow stations with little or no streamflow data when the streams in the basin are flowing at rates approximately equal to their averageannual ground-water runoff. This was done at several stations along the lower Santa Fe River during August 1996 when the discharge at the Santa Fe River near Fort White gaging station (station 17) was approximately equal to the average-annual ground-water runoff.

Streamflow data from stations in the middle Suwannee River basin (at and below the Suwannee
River at Ellaville (site 8 in fig. 4 and table 4, above)) and in the lower Santa Fe River downstream from the river rise north of High Springs (site 15) were the primary source of information for estimating recharge rates to the Upper Floridan aquifer. These streams were selected because their flows are sustained by high rates of ground-water discharge from the contiguous Upper Floridan aquifer. This pattern of high ground-water runoff is consistent with the configuration of the potentiometric surface of the Upper Floridan aquifer (fig. 8). Contour lines that define this surface form a "valley" around the Suwannee and Santa Fe Rivers near and downstream from the confluence of the Suwannee and Withlacoochee Rivers, and 


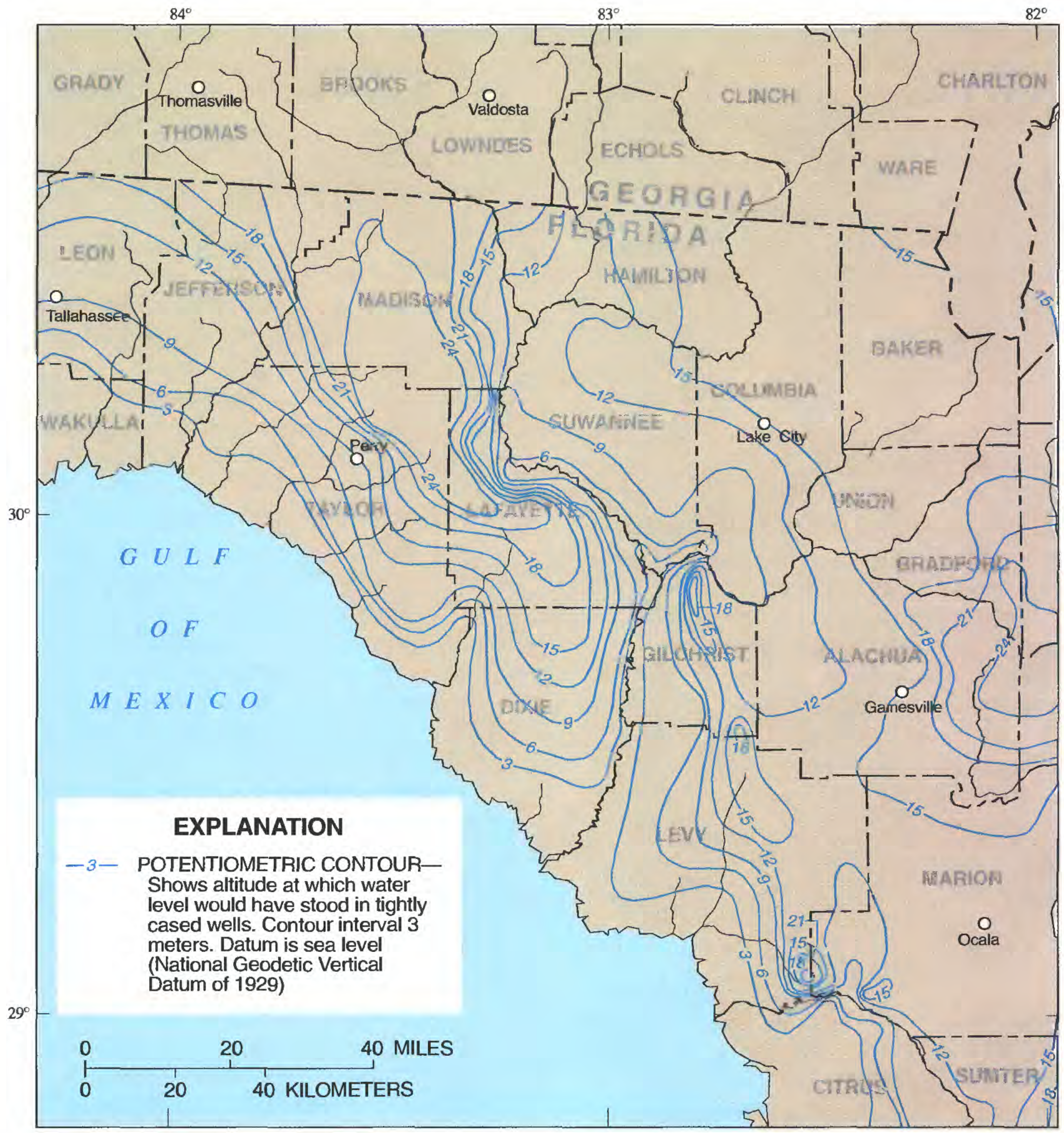

Figure 8. Potentiometric surface of the Upper Floridan aquifer in the Suwannee River Water Management District in May and June 1995.

downstream from the reemergence of the Santa Fe River (site 15 in fig. 4). This pattern indicates that ground-water discharge from the Upper Floridan aquifer is relatively high in these reaches. Streamflow data from other stations were also evaluated to estimate the ground-water runoff in streams draining highlands areas. Ground-water runoff in these streams is sustained by ground-water discharge from the surficial aquifer system.
Base flow-separation analyses of data from these streamflow stations indicated that ground-water runoff ranged from approximately 12 to $86 \mathrm{~cm} / \mathrm{yr}$ (table 4). The highest ground-water runoff estimates were obtained from stations in the middle reach of the Suwannee River (sites 8, 9, and 10) and ranged from 70 to $86 \mathrm{~cm} / \mathrm{yr}$ (table 4). Ground-water runoff values of the stations in the middle and lower reaches of the Suwannee River and the lower reach of the Santa Fe 
River are much higher than the ground-water discharge from the Upper Floridan aquifer to these reaches. This arises because these ground-water runoff values also include ground-water discharge from the surficial aquifer system to highland streams (where the Upper Floridan aquifer is generally confined or poorly confined) that are tributaries to the Suwannee and Santa Fe Rivers. This last statement is represented schematically in figure 3 (in the ground-water runoff from lowland streams) and with the following equation:

$$
Q_{G W}=Q_{U F A}+Q_{S A S}
$$

where $Q_{U F A}$ is ground-water runoff derived from the Upper Floridan aquifer, $Q_{S A S}$ is ground-water runoff derived from the surficial aquifer system, and $Q_{G W}$ is the combined ground-water runoff derived from both sources (which is the estimate obtained from the baseflow-separation analysis).

To improve the estimates of ground-water runoff from the Upper Floridan aquifer (and, therefore, recharge rates to the Upper Floridan aquifer), estimates of ground-water runoff values $\left(Q_{G W}\right)$ in the middle and lower Suwannee River and the lower Santa Fe River were adjusted using estimates of groundwater runoff from the surficial aquifer system $\left(Q_{S A S}\right)$. This was accomplished by rearranging equation 10 as follows:

$$
Q_{U F A}=Q_{G W}-Q_{S A S} .
$$

$Q_{\text {SAS }}$ was estimated using the results of base flow separation analyses of runoff from highland streams draining the surficial aquifer system.

For stations in the lower Santa Fe River, $Q_{S A S}$ was set equal to the ground-water runoff computed for site 14 (Santa Fe River at O'leno State Park) using base flow-separation analysis. Site 14 was selected because it captures nearly all of the ground-water runoff from the surficial aquifer system in the Santa Fe River Basin. As shown in table 4, the ground-water runoff of site 14 is $11.8 \mathrm{~m}^{3} / \mathrm{s}$. This value was substituted for the $Q_{S A S}$ term when equation 11 was applied to sites 15 through 18 in the lower reach of the Santa Fe River.

For stations in the middle Suwannee River Basin, $Q_{S A S}$ was computed by estimating the combined ground-water runoff of highland streams draining the surficial aquifer system in the upper Suwannee,
Alapaha, and Withlacoochee River Basins. The combined ground-water runoff from sites 3,6 , and 7 was $94.6 \mathrm{~m}^{3} / \mathrm{s}$ and comprised most of $Q_{S A S}$ for these stations. However, insufficient streamflow data precluded estimating ground-water runoff (using the techniques previously described in this section) from most of an area contributing $Q_{S A S}$ in tributaries to the Suwannee River below site 2 and above the mouth of the Alapaha River. The ground-water runoff from this area was estimated by multiplying the size of the area $\left(1,436 \mathrm{~km}^{2}\right)$ by the median ground-water runoff of three gaged streams occurring in this area (sites 2, 4, and 5), and multiplying by a conversion factor to yield an estimate of $10.0 \mathrm{~m}^{3} / \mathrm{s}$. This value was then added to the above value of $94.6 \mathrm{~m}^{3} / \mathrm{s}$, which yielded an estimated $Q_{S A S}$ value of $104.6 \mathrm{~m}^{3} / \mathrm{s}$. This value of $Q_{S A S}$ was used to apply equation 11 to sites 8 through 10 in the middle Suwannee River Basin.

For stations in the lower Suwannee River (sites 19 and 20), $Q_{S A S}$ was estimated by summing the $Q_{S A S}$ values applied to stations in the lower Santa Fe Basin $\left(Q_{S A S}=11.8 \mathrm{~m}^{3} / \mathrm{s}\right)$ and the middle Suwannee River $\left(Q_{S A S}=104.6 \mathrm{~m}^{3} / \mathrm{s}\right)$. The result of this summation $\left(116.4 \mathrm{~m}^{3} / \mathrm{s}\right)$ was used for the value of $Q_{S A S}$ when equation 11 was applied to estimate $Q_{U F A}$ at sites 19 and 20.

The $Q_{U F A}$ values that are described above are shown in parentheses in table 4 , next to the uncorrected base flow $\left(Q_{G W}\right)$ values. The $Q_{U F A}$ values of the middle and lower Suwannee River stations ranged from 28 to $32 \mathrm{~cm} / \mathrm{yr}$. In the lower Santa Fe River, $Q_{U F A}$ estimates ranged from ranged from 5 to $30 \mathrm{~cm} / \mathrm{yr}$.

Changes in ground-water runoff that occurred between stations were evaluated for stations in the middle and lower Suwannee River and the lower Santa Fe River (table 5). Recharge estimates from these comparisons ranged from 30 to $57 \mathrm{~cm} / \mathrm{yr}$. In some cases, the increases in ground-water runoff that occurred between two stations exceeded the increase in total runoff. The largest exceedance occurred in the reach of the Suwannee River between sites 8 and 10 , where ground-water runoff increased by $22.1 \mathrm{~m}^{3} / \mathrm{s}$ $(30 \mathrm{~cm} / \mathrm{yr})$ and total runoff increased by only $14.8 \mathrm{~m}^{3} / \mathrm{s}$ $(20 \mathrm{~cm} / \mathrm{yr})$. Similarly, the increase in ground-water runoff also slightly exceeded the increase in total runoff in the Santa Fe River between sites 16 and 17.

The most likely explanation for ground-water runoff changes exceeding changes in total runoff is that some of the direct runoff that flows into the reach 
Table 5. Change in total runoff and ground-water runoff between selected streamflow stations

$\left[\mathrm{km}^{2}\right.$, square kilometers; $\mathrm{m}^{3} / \mathrm{s}$. cubic meters per second; $\mathrm{cm} / \mathrm{yr}$. centimeters per year]

\begin{tabular}{|c|c|c|c|c|c|c|}
\hline \multirow{2}{*}{ Upstream station name } & \multirow{2}{*}{ Downstream station name } & \multirow{2}{*}{$\begin{array}{c}\text { Area } \\
\text { contributing } \\
\text { ground water, } \\
\left(\mathrm{km}^{2}\right)\end{array}$} & \multicolumn{2}{|c|}{$\begin{array}{l}\text { Increase in total } \\
\text { annual runoff }{ }^{1}\end{array}$} & \multicolumn{2}{|c|}{$\begin{array}{l}\text { Increase in ground- } \\
\text { water runoff }{ }^{1}\end{array}$} \\
\hline & & & $\left(\mathrm{m}^{3} / \mathrm{s}\right)$ & $(\mathrm{cm} / \mathrm{yr})$ & $\left(\mathrm{m}^{3} / \mathrm{s}\right)$ & (cm/yr) \\
\hline Suwannee River at Ellaville & Suwannee River at Branford & 2,344 & 14.8 & 20 & 22.1 & 30 \\
\hline Santa Fe River near High Springs & Santa Fe River near Fort White & 1,779 & 21.9 & 39 & 22.3 & 40 \\
\hline $\begin{array}{l}\text { Suwannee River at Branford } \\
\text { Santa Fe River near Fort White }\end{array}$ & Suwannee River near Bell & 2,421 & 37.6 & 49 & 27.4 & 36 \\
\hline Suwannee River near Bell & Suwannee River near Wilcox & 960 & 17.5 & 57 & 17.3 & 57 \\
\hline $\begin{array}{l}\text { Suwannee River at Branford } \\
\text { Santa Fe River near Fort White }\end{array}$ & Suwannee River near Wilcox & 3,368 & 54.9 & 51 & 45.1 & 42 \\
\hline
\end{tabular}

${ }^{1}$ Values reported in $\mathrm{cm} / \mathrm{yr}$ units were calculated by dividing runoff by area contributing ground water.

recharges the aquifer at high flows, when the river stages are higher than hydraulic heads (water levels) in the aquifer. As the stage in the river declines following the high river flows, the river water that recharged the aquifer is released from the aquifer (back into the river) and accounts for base flow in the downstream station. Evidence of this phenomena in the Suwannee River area includes observations of reverse flow in springs, and ground water that becomes tannin-stained during and subsequent to high river flows. This type of recharge also occurs in the Suwannee River below Branford and in the lower Santa Fe River Basin, but it represents a much smaller fraction of total recharge in these reaches because the difference between river and ground-water levels during floods is smaller.

The relation between recharge and confinement was evaluated by comparing ground-water runoff values to the degree of confinement of the contributing area. A strong association was evident between recharge and the percentage of the contributing area that was unconfined, poorly confined, or confined. $Q_{U F A}$ values were approximately 5 to $18 \mathrm{~cm} / \mathrm{yr}$ for the Santa Fe River near Traxler and High Springs stations (table 4). Only 5 to 11 percent of the contributing areas of these two stations was unconfined. Conversely, recharge was much higher $(57 \mathrm{~cm} / \mathrm{yr})$ in the area between the Bell (site 19) and Wilcox (site 20) stations on the Suwannee River, where 95 percent of the area was unconfined.

A regression model was developed to quantify this relation between recharge and confinement of the Upper Floridan aquifer. The data set used to develop this relation is presented in table 6 . All possible combinations of the three explanatory variables (percentage of contributing area that is confined, poorly confined, and unconfined) were evaluated. The best model was one that included two variables: the percentage that was confined and the percentage of the contributing area that was poorly confined. This model was selected because it had the lowest Mallow's Cp statistic (Helsel and Hirsch, 1992, p. 313) among models with regression coefficients that were significant at a confidence level of 95 percent or better. The equation for this model is:

$$
R=62.7-0.571 C-0.366 P,
$$

where $R$ is recharge, in centimeters per year, and $C$ and $P$ are the percentages of the contributing area that are confined and poorly confined, respectively.

The relation between recharge estimated from the base-flow analysis, model estimated recharge (from equation 12 , above), and $C, P$, and the percentage of the contributing area that is unconfined is shown in the three graphs in figure 9. The model predictions of recharge generally corresponded closely with the observed values. The root mean square error and adjusted $\mathrm{R}^{2}$ of the regression model are $4.9 \mathrm{~cm} / \mathrm{yr}$ and 0.84 , respectively. In areas where the Upper Floridan aquifer is confined everywhere ( $C=100$ and $P=0$ ), the model estimate of recharge is $6 \mathrm{~cm} / \mathrm{yr}$, with a prediction interval (at a 95-percent level of confidence) of 0 to $21 \mathrm{~cm} / \mathrm{yr}$ (table 7). In areas where the Upper Floridan aquifer is poorly confined everywhere ( $C=0$ and $P=100$ ), the model estimate of recharge is $26 \mathrm{~cm} / \mathrm{yr}$, with a prediction interval of 9 to $43 \mathrm{~cm} / \mathrm{yr}$ (table 7). In areas where the Upper Floridan aquifer is unconfined everywhere ( $C=0$ and $P=0$ ), the model estimate of recharge is $63 \mathrm{~cm} / \mathrm{yr}$, 
Table 6. Data used to develop regression model relating recharge to confinement of the Upper Floridan aquifer $\left[\mathrm{km}^{2}\right.$, square kilometers; $\mathrm{m}^{3} / \mathrm{s}$, cubic meters per second; $\mathrm{cm} / \mathrm{yr}$, centimeters per year; --, not applicable]

\begin{tabular}{|c|c|c|c|c|c|c|}
\hline $\begin{array}{l}\text { Station name } \\
\text { (see fig. } 4 \text { ) }\end{array}$ & Downstream station name & $\begin{array}{l}\text { Area con- } \\
\text { tributing } \\
\text { ground } \\
\text { water, } \\
\left(\mathbf{k m}^{2}\right)\end{array}$ & $\begin{array}{l}\text { Recharge, } \\
\text { (cm/yr) }\end{array}$ & $\begin{array}{l}\text { Confined } \\
\text { area, as a } \\
\text { percentage } \\
\text { of the total } \\
\text { contributing } \\
\text { area }\end{array}$ & $\begin{array}{l}\text { Poorly con- } \\
\text { fined area, } \\
\text { as a per- } \\
\text { centage of } \\
\text { the total } \\
\text { contribut- } \\
\text { ing area }\end{array}$ & $\begin{array}{l}\text { Uncon- } \\
\text { fined area, } \\
\text { as a per- } \\
\text { centage of } \\
\text { the total } \\
\text { contribut- } \\
\text { ing area }\end{array}$ \\
\hline Suwannee River at Ellaville (site 8) & - & 6,006 & 31 & 50 & 32 & 18 \\
\hline Suwannee River at Branford (site 10) & - & 8,350 & 30 & 36 & 28 & 37 \\
\hline Santa Fe River near Traxler (site 15) & -- & 1,396 & 5 & 67 & 28 & 5 \\
\hline $\begin{array}{l}\text { Santa Fe River near High Springs } \\
\text { (site 16) }\end{array}$ & - & 1,541 & 18 & 62 & 27 & 11 \\
\hline $\begin{array}{l}\text { Santa Fe River near Fort White } \\
\text { (site 17) }\end{array}$ & - & 3,321 & 30 & 42 & 31 & 27 \\
\hline $\begin{array}{l}\text { Mouth of Santa Fe River near } \\
\text { Branford (site 18) }\end{array}$ & - & 5,361 & 23 & 42 & 32 & 26 \\
\hline Suwannee River near Bell (site 19) & - & 14,092 & 31 & 37 & 29 & 34 \\
\hline Suwannee River near Wilcox (site 20) & - & 15,642 & 32 & 35 & 27 & 38 \\
\hline Suwannee River at Ellaville & Suwannee River at Branford & 2,344 & 30 & 0 & 83 & 17 \\
\hline Santa Fe River near High Springs & Santa Fe River near Fort White & 1,779 & 40 & 24 & 35 & 42 \\
\hline $\begin{array}{l}\text { Suwannee River at Branford } \\
\text { Santa Fe River near Fort White }\end{array}$ & Suwannee River near Bell & 2,421 & 36 & 36 & 28 & 36 \\
\hline Suwannee River near Bell & Suwannee River near Wilcox & 960 & 57 & 0 & 5 & 95 \\
\hline $\begin{array}{l}\text { Suwannee River at Branford } \\
\text { Santa Fe River near Fort White }\end{array}$ & Suwannee River near Wilcox & 3,368 & 42 & 26 & 22 & 52 \\
\hline
\end{tabular}

with a prediction interval of 48 to $77 \mathrm{~cm} / \mathrm{yr}$ (table 7 ). These results were obtained using the corrected base flow values and, therefore, do not include direct recharge to the Upper Floridan from stream capture by sinkholes.

\section{Chemical Base-Flow Separation}

Chemical base-flow separation was used in the study to corroborate some of the results of the hydrometric base-flow analysis. The chemical base-flow separation method used in this study utilizes stream discharge and specific conductance data from ground, stream, and direct runoff waters. Similar applications of this method are found in Pinder (1969) and Freeze and Cherry (1979, p. 223). This method has been previously applied in Florida by Toler (1965) to evaluate ground-water discharge to Econfina Creek in northwestern Florida.

The method is derived from water and chemical mass-balance equations for a stream reach. The water budget for a stream reach can be described as follows:

$$
Q_{D S}-Q_{U S}=Q_{G W}+Q_{D},
$$

where $Q_{D S}$ is the average streamflow out of the downstream end of the stream reach, $Q_{U S}$ is the average streamflow into the upstream end of the reach, $Q_{G W}$ is the average ground-water flow into the reach, and $Q_{D}$ is the average direct (storm) runoff into the reach. Contributions from precipitation over the stream surface and evaporation losses from the stream surface are assumed to be negligible. The mass balance for a chemical or set of chemicals flowing in the reach can be expressed as follows:

$$
\begin{aligned}
M_{D S}-M_{U S} & =Q_{D S} C_{D S}-Q_{U S} C_{U S} \\
& =\left(Q_{G W} C_{G W}+Q_{D} C_{D}\right)
\end{aligned}
$$

where $M_{D S}$ is the average mass flux (mass per unit time) of a given chemical across the downstream boundary of the reach; $M_{U S}$ is the average mass flux the chemical across the upstream boundary of the reach; $C_{D S}$ is the concentration of the chemical at the downstream boundary at a level of flow equal to $Q_{D S}$, which is the average streamflow at the downstream boundary; $C_{U S}$ is the concentration of the chemical at the upstream boundary at a level of flow equal to $Q_{U S}$, 

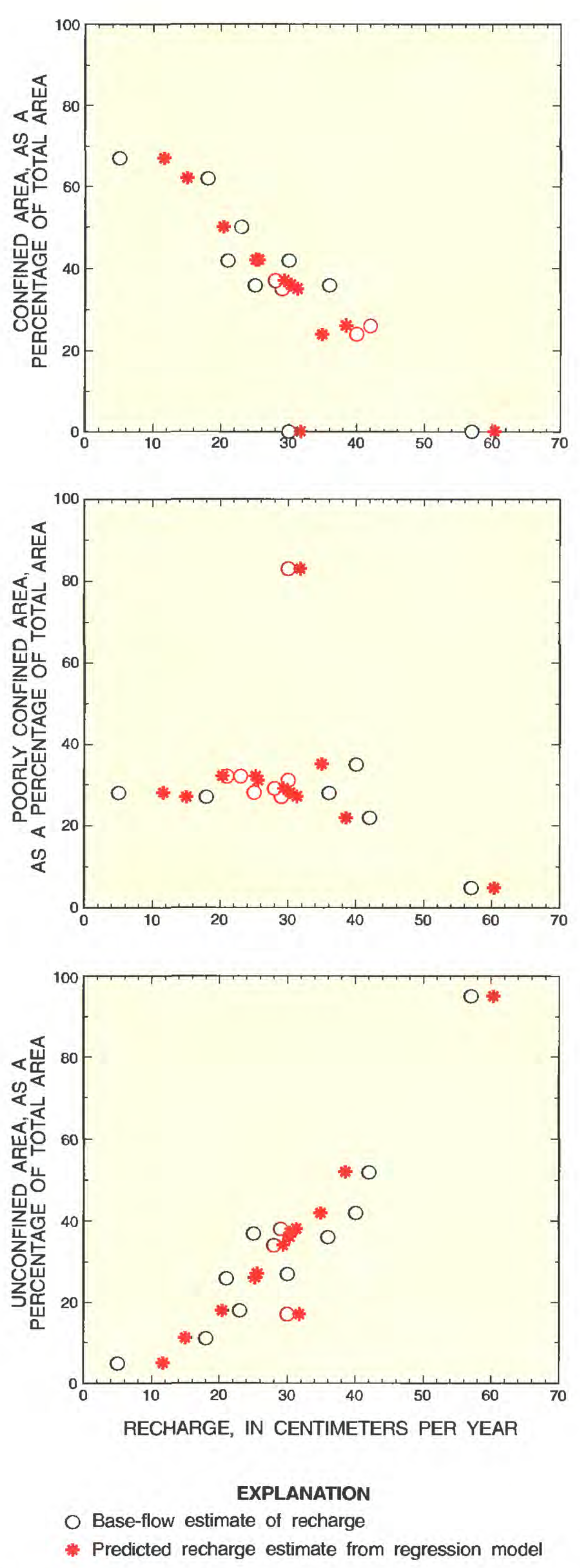

Figure 9. Relation between aquifer confinement and recharge in selected ground-water basins in the Suwannee River Water Management District. which is the average streamflow at the upstream boundary; $C_{G W}$ is the average concentration of ground-water discharge, $Q_{G W}$, to the reach and $C_{D}$ is the average concentration of direct runoff, $Q_{D}$, to the reach. In this study, specific-conductance values were used in place of the concentration terms in equation 14.

Equation 13 can be rearranged to express the water budget in terms of $Q_{D}$ :

$$
Q_{D}=Q_{D S}-Q_{U S}-Q_{G W},
$$

and the resulting expression can be substituted into equation 14 to yield the following equation:

$$
\begin{gathered}
Q_{D S} C_{D S}-Q_{U S} C_{U S}=Q_{G W} C_{G W} \\
+\left(Q_{D S}-Q_{U S}-Q_{G W}\right) C_{D}
\end{gathered} .
$$

Equation 16 can be rearranged to yield an expression for $Q_{G W}$ :

$$
\begin{aligned}
Q_{G W} & =\left[\left(Q_{D S}-Q_{U S}\right) C_{D}\right. \\
& \left.-\left(Q_{D S} C_{D S}-Q_{U S} C_{U S}\right)\right] /\left(C_{D}-C_{G W}\right) .
\end{aligned}
$$

In this study, the chemical base-flow separation method was used to estimate inflows of direct runoff and ground water in the reach of the Santa Fe River between the Worthington Springs and Fort White gaging stations (sites 13 and 17, respectively; fig. 4). This was accomplished by evaluating specific-conductance data in ground, stream, and direct runoff water and streamflow data from the two gaging stations, and applying the equation 17 as follows:

$$
\begin{aligned}
Q_{G W}= & {\left[\left(Q_{17}-Q_{13}\right) C_{D}-\left(Q_{17} C_{17}-Q_{13} C_{13}\right)\right.} \\
& /\left(C_{D}-C_{G W}\right)
\end{aligned}
$$

where $Q_{G W}$ is the average-annual ground-water discharge from the Upper Floridan aquifer to the reach between sites 13 and $17 ; Q_{17}$ and $Q_{13}$ are the average-annual discharge (total runoff) at sites 13 and 17 , respectively; $C_{17}$ and $C_{13}$ are the average specific conductance values at sites 17 and 13 , respectively, when discharges at these stations equal $Q_{17}$ and $Q_{13}$, respectively; $C_{D}$ is the average specific conductance of direct runoff water; and $C_{G W}$ is the average specific conductance of ground water that is discharged from the Upper Floridan aquifer into the reach between sites 13 and 17 . 
Table 7. Results from regression analysis of aquifer recharge and aquifer confinement

[cm/yr, centimeters per year]

\begin{tabular}{lccc}
\hline $\begin{array}{c}\text { Degree of } \\
\text { confinement }\end{array}$ & $\begin{array}{c}\text { Predicted } \\
\text { recharge, } \\
\text { (cm/yr) }\end{array}$ & $\begin{array}{c}\text { Standard } \\
\text { deviation of } \\
\text { prediction, } \\
\text { (cm/yr) }\end{array}$ & $\begin{array}{c}\text { 95-percent } \\
\text { confidence } \\
\text { interval for } \\
\text { predictions, } \\
\text { (cm/yr) }\end{array}$ \\
\hline Confined & 6 & 7 & 0 to 21 \\
$\begin{array}{c}\text { Poorly } \\
\text { confined }\end{array}$ & 26 & 8 & 9 to 43 \\
Unconfined & 63 & 7 & 48 to 77 \\
\hline
\end{tabular}

Continuous specific-conductance measurements were made at both gages from April through October 1996. These data were used to develop relations between specific conductance and discharge that were used to estimate values of $C_{17}$ and $C_{13}$ in equation 18. Between April and October 1996, specific- conductance values at site 17 ranged from approximately 100 to 400 microsiemens per centimeter $(\mu S / \mathrm{cm})$, and the average value was approximately $340 \mu \mathrm{S} / \mathrm{cm}$ (fig. 10). Values ranged from 50 to $200 \mu \mathrm{S} / \mathrm{cm}$ and averaged $115 \mu \mathrm{S} / \mathrm{cm}$ at site 13 . Changes in specific-conductance values at sites 13 and 17 were inversely proportional to changes in discharge at the two stations (fig. 10). The highest specificconductance values were observed during periods of low flow and the lowest conductance values were observed during high flow periods. This relation between specific conductance and discharge occurs because low-conductance water from direct runoff accounts for a larger proportion of total flow in the reach during periods of high flow, and highconductance ground-water discharge represents a larger proportion of total flow at low flow. Relations
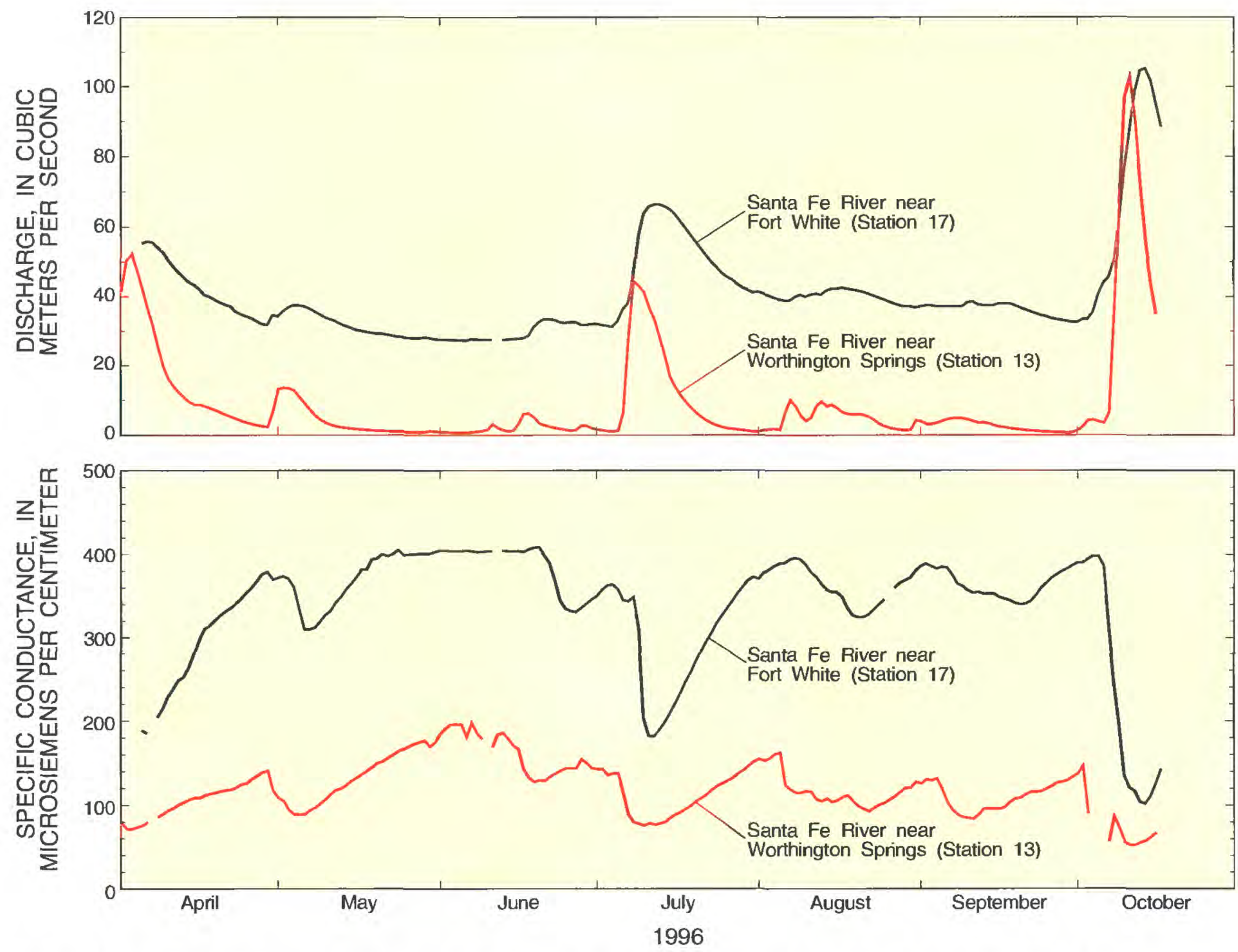

Figure 10. Relation between specific conductance and stream discharge in the Santa Fe River at sites 13 (near Worthington Springs) and 17 (near Fort White) (sites shown in fig. 4). 
Table 8. Data and results of the chemical base-flow separation analysis of the Santa Fe River between the Worthington Springs (site 13) and Fort White (site 17) gaging stations

$\left[\mathrm{m}^{3} / \mathrm{s}\right.$, cubic meters per second; $\mu \mathrm{S} / \mathrm{cm}$, microsiemens per centimeter. Stations shown in fig. 4]

\begin{tabular}{|c|c|}
\hline \multicolumn{1}{|c|}{ Variable } & Value \\
\hline $\begin{array}{c}\text { Average-annual discharge in the Santa Fe River } \\
\text { near Worthington Springs }\left(Q_{13}\right)\end{array}$ & $12.4 \mathrm{~m}^{3} / \mathrm{s}$ \\
\hline $\begin{array}{c}\text { Average-annual discharge in the Santa Fe River } \\
\text { near Fort White }\left(Q_{17}\right)\end{array}$ & $44.8 \mathrm{~m}^{3} / \mathrm{s}$ \\
\hline $\begin{array}{c}\text { Average specific conductance value in the Santa } \\
\text { Fe River near Worthington Springs }\left(C_{13}\right)\end{array}$ & $100 \mu \mathrm{S} / \mathrm{cm}$ \\
\hline $\begin{array}{c}\text { Average specific conductance value in the Santa } \\
\text { Fe River near Fort White }\left(C_{17}\right)\end{array}$ & $300 \mu \mathrm{S} / \mathrm{cm}$ \\
\hline $\begin{array}{c}\text { Average specific conductance in ground water } \\
\text { from the Upper Floridan aquifer }\left(C_{G W}\right)\end{array}$ & $370 \mu \mathrm{S} / \mathrm{cm}$ \\
\hline Average specific conductance in direct runoff $\left(C_{D}\right)$ & $55 \mu \mathrm{S} / \mathrm{cm}$ \\
\hline $\begin{array}{c}\text { Ground-water infiow to the Santa Fe River } \\
\text { between sites } 13 \text { and } 17\left(Q_{G W}\right)\end{array}$ & $33.1 \mathrm{~m}^{3} / \mathrm{s}$ \\
\hline
\end{tabular}

between specific conductance and discharge at the two stations indicated that values of $C_{17}$ and $C_{13}$ should be approximately equal to 300 and $100 \mu \mathrm{S} / \mathrm{cm}$. respectively (table 8 , above).

Specific-conductance data for ground and spring water in the area adjacent to this reach were obtained from data bases maintained by the SRWMD, the Florida Department of Environmental Protection. and the USGS. A limited number of spring-water samples were also collected during the study. Samples of ground water from area wells that were open to the Upper Floridan aquifer generally had specific conductance values between 250 to $400 \mu \mathrm{S} / \mathrm{cm}$. Springs discharging water to the reach between sites 13 and 17 had specific-conductance values that ranged from approximately 300 to $450 \mu \mathrm{S} / \mathrm{cm}$, and the volumeweighted mean concentration from these springs was approximately $370 \mu \mathrm{S} / \mathrm{cm}$. The latter value was used to estimate $C_{G W}$ (table 8 ).

Samples of direct runoff and data from the gages at sites 13 and 17 were used to estimate the specific conductance of direct runoff to the Santa Fe River in the reach between those stations. Samples of direct runoff from some of the smaller tributaries in this area were collected during or shortly after periods of intense rainfall. The specific conductance of direct runoff to the Worthington Springs to Fort White reach of the Santa Fe River was estimated to be between 30 and $80 \mu \mathrm{S} / \mathrm{cm}$, and a value of $55 \mu \mathrm{S} / \mathrm{cm}$ was used to estimate $C_{D}$ (table 8 ). This estimate was based on samples collected from ephemeral streams (Rose
Creek and Clay Hole Sink) near this reach, small tributaries to this reach, and data from the Santa Fe River at Worthington Springs and at Graham during periods of peak runoff. Specific conductance values in rainfall were generally between 10 and $20 \mu \mathrm{S} / \mathrm{cm}$.

Results from the chemical base-flow analysis indicated that ground-water discharge accounts for all or nearly all of the increase in flow in the Santa Fe River between sites 13 and 17. For example, applying equation 18 with the values of $C_{13}, C_{17}, C_{G W}$, and $C_{D}$ from table 8 results in an estimated value of $33.1 \mathrm{~m}^{3} / \mathrm{s}$ for $Q_{G W}$, which is approximately equal to the total change in average-annual flow between sites 13 and $17\left(32.4 \mathrm{~m}^{3} / \mathrm{s}\right)$. Uncertainties in the values of $C_{13}, C_{I 7}$ and $C_{G W}$ are probably the reason that $Q_{G W}$ slightly exceeds $Q_{17}-Q_{13}$ (the results of the analysis were insensitive to uncertainties in $Q_{D}$ ). Other estimates of $Q_{G W}$ were also computed by varying $C_{13} \cdot C_{I 7}, C_{D}$ and $C_{G W}$ within their ranges of uncertainty. These estimates also indicated that $Q_{G W}$ was generally at least 96 percent of $Q_{17}-Q_{13}$. These results are consistent with the results from the hydrometric base-flow analysis, which indicated that ground-water discharge accounted for practically all of the increase in discharge between the Worthington Springs and Fort White gages.

\section{ANALYSIS OF WATER-LEVEL CHANGES IN SHALLOW WELLS}

Recharge estimates may also be made by analyzing water-level changes in shallow wells (Grubbs, 1995a). The method is based on a simple model in which recharge is estimated as the product of specific yield and the sum of daily water-level changes and recession rates:

$$
\begin{gathered}
R=S_{y} \sum_{i=1}^{N}\left(\Delta h_{i}+\bar{h}_{\text {recess }, i}\right) \text { for } \Delta h+\bar{h}_{\text {recess, } i}>0 \\
R=0 \text { for } \Delta h+h_{\text {recess }, i} \leq 0
\end{gathered}
$$

where $S_{y}$ is the specific yield, $\Delta h$ is the waterlevel change during time interval $i, h_{\text {recess, } i}$ is the water-level decline that would be expected to occur in the absence of recharge (fig. 11d), and $N$ is the number of time intervals over which recharge is being 


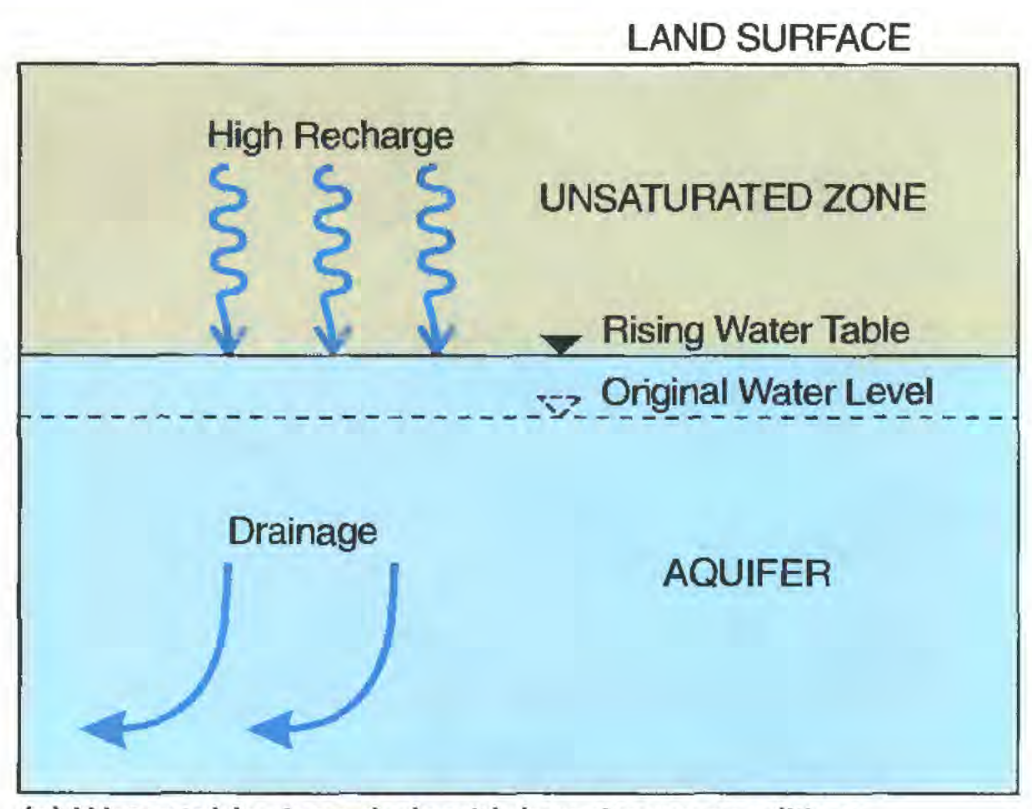

(a) Water table rises during high recharge conditions because recharge exceeds drainage.

LAND SURFACE

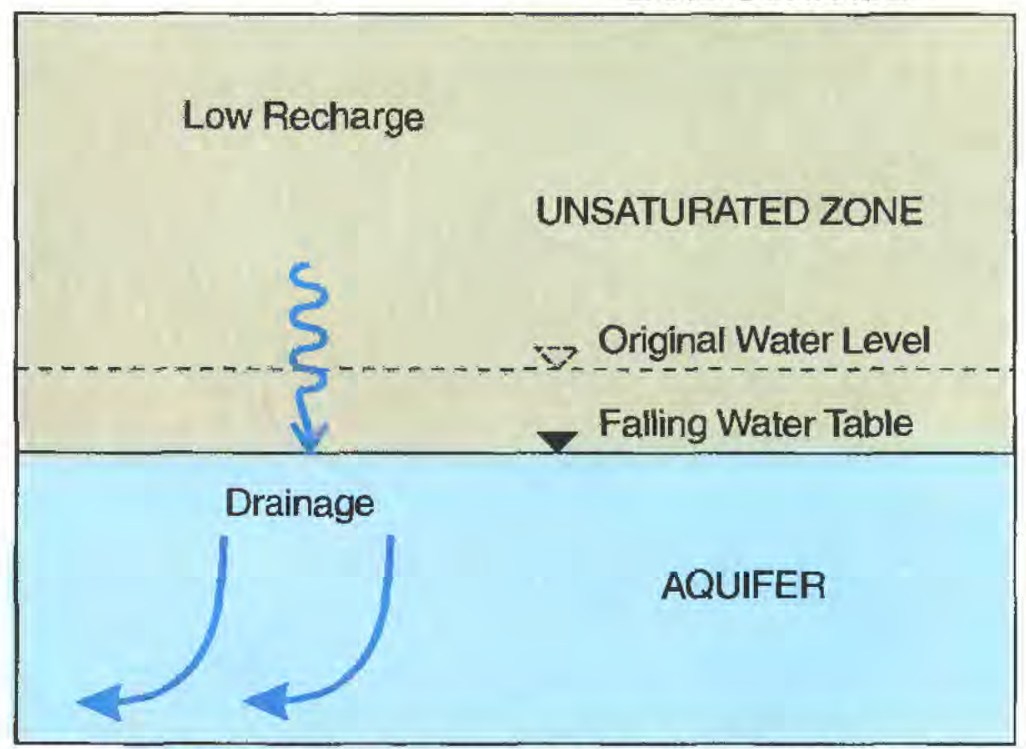

(c) Water table falls during low recharge conditions because drainage exceeds recharge.

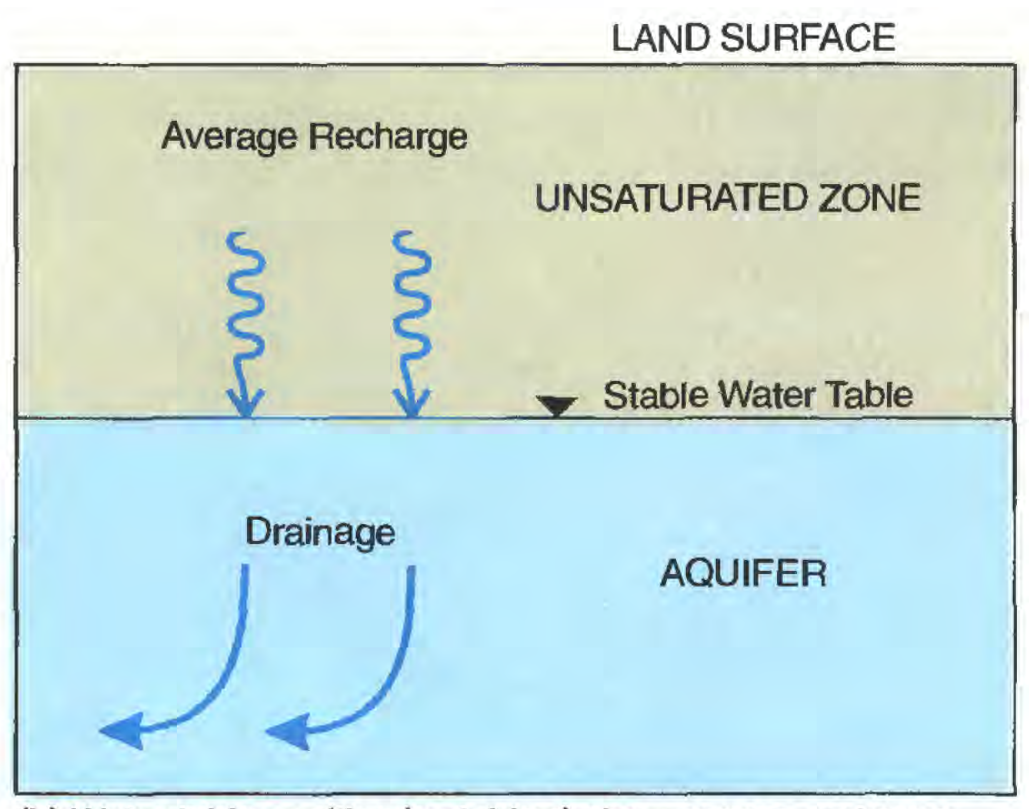

(b) Water table position is stable during average recharge conditions because recharge equals drainage.

LAND SURFACE

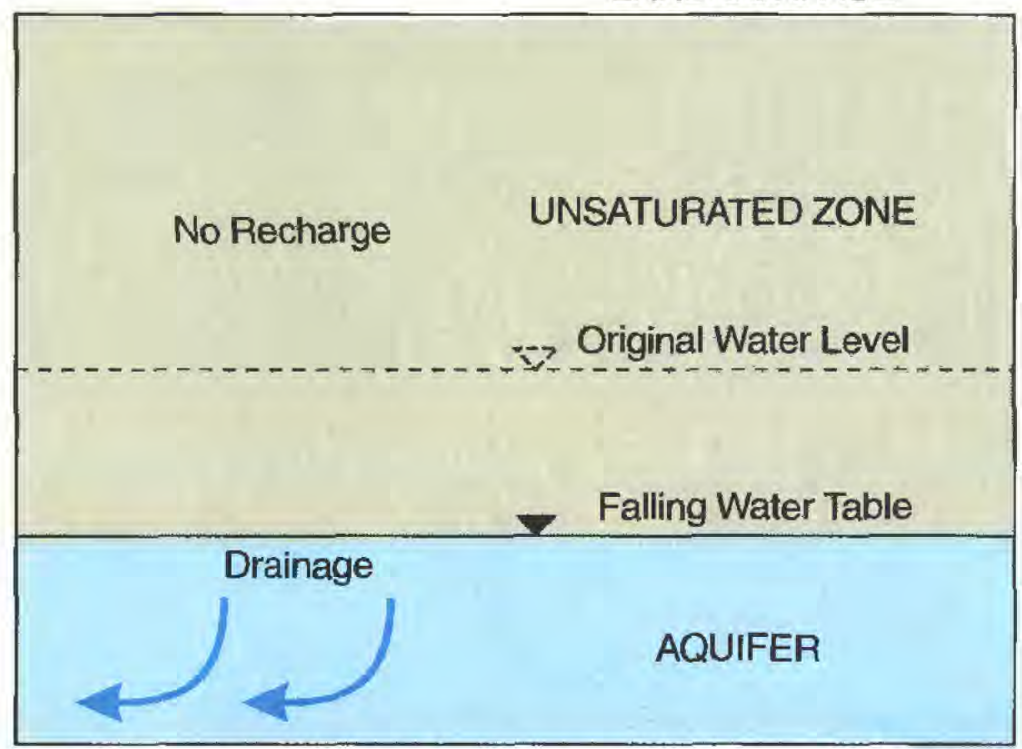

(d) Water table position falls during periods of no recharge because drainage from recharge area continues.

Figure 11. Relation between recharge, ground-water drainage from recharge area and movement of water table.

computed (for example, if $i$ is equal to 1 day and annual recharge is needed, then $N$ is equal to 365 ).

Several requirements are necessary for the successful application of equations 19 and 20. First, the sediments in and immediately above the zone of water-table fluctuations must drain rapidly and completely. This condition is necessary, because the volume of sediment that is filled or drained by a given rise or fall in the water table is assumed to be equivalent to the specific yield of the sediments. Second, specific yield must be known with an acceptable degree of accuracy. Finally, estimates of $h_{\text {recess, } i}$ are needed to account for the water-level declines that would occur in the absence of recharge (because of ground-water flow away from the recharge area). In this study, a relation between $h_{\text {recess, } i}$ and the elevation of the water table was developed by analyzing ground-water level recession rates (fig. 12). This rela- tion made it possible to estimate $h_{\text {recess, } i}$ if the watertable elevation was known.

When missing data make it difficult to apply equations 19 and 20, the following equation can be used to estimate an average-annual recharge rate:

$$
\bar{R}=S_{y} \bar{h}_{\text {recess }}
$$

where $\bar{R}$ is the average-annual recharge rate and $\bar{h}$ is the average, long-term water-table recession rate. Equation 21 is based on the assumption that recharge is equal to ground-water drainage over long periods of time.

Water-level data from the City of Trenton well and the Alto Straughn well (fig. 2) were analyzed using the methods described above. Both of these 


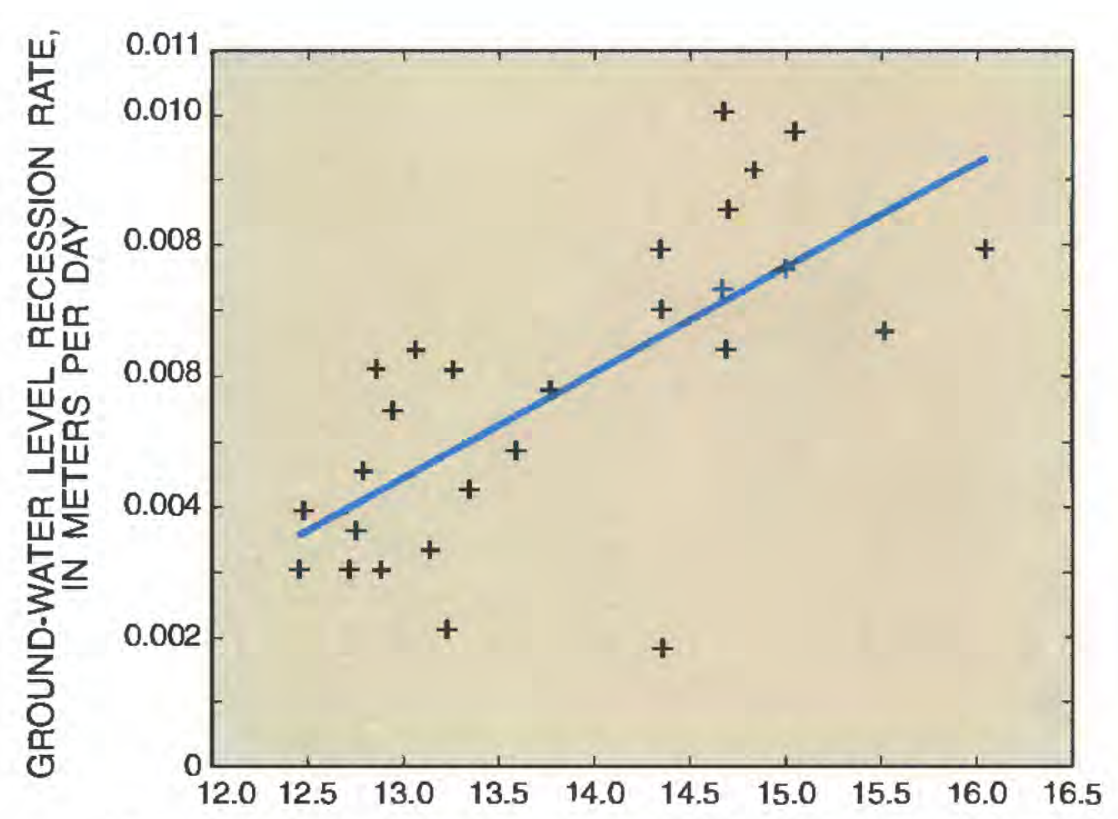

GROUND-WATER LEVEL, IN METERS ABOVE SEA LEVEL

Figure 12. Relation between ground-water level and ground-water level recession rate at the Alto Straughn well (location shown in fig. 2).

wells are located in areas where the intermediate confining unit is absent. Lithologic logs indicated that water-table fluctuations in these wells occurred within a zone of sand or limestone. Daily, monthly, and average-annual recharge rates were estimated at the Alto Straughn well, using equations 19 and 20. Averageannual recharge was estimated at the City of Trenton well using equation 21 .

The recharge analyses for the two wells yielded average-annual recharge estimates that, although imprecise, were fairly consistent. Estimates of average-annual recharge were within a range of 17 to $66 \mathrm{~cm} / \mathrm{yr}$ at the City of Trenton well and 28 to $83 \mathrm{~cm} / \mathrm{yr}$ at the Alto Straughn well. Similar results were obtained from a fourth well, the Vernon Norton well (fig. 2); however, the reliability of these results is questionable, because the water table fluctuates within a zone of clay sediments. The large (approximately $50 \mathrm{~cm} / \mathrm{yr}$ ) differences between the lower and upper estimate of recharge at each well reflects the uncertainty in the specific yield, which was assumed to be within a range of $0.1-0.3$.

Perhaps the most useful application of the ground-water level change method is in evaluating temporal patterns in recharge and their relation to temporal patterns in rainfall. This evaluation was made for the Alto Straughn well because of the long period of record at this station. The results indicate that recharge rates are typically highest from February through April and from August through October. Recharge rates also appear to be more variable in these months (fig. 13a). These seasonal recharge patterns are explained only partially by seasonal rainfall patterns. Rainfall data from the nearby Archer Fire Tower (which is approximately $6 \mathrm{~km}$ east of the Alto Straughn well) indicate that about half of the annual rainfall occurs from June through September (fig. 13b). Differences between the temporal patterns of ground-water recharge and rainfall are indicated by the distribution of the ratio of recharge and precipitation (recharge efficiency, fig. 13c). This ratio is highest during March, April, and October when approximately 30 to 35 percent of rainfall results in recharge. Thus, these months have some of the highest median recharge rates, even though the rainfall in these months is lower than the high rainfall months of June through September. Conversely, the wet months of June through September have much lower recharge efficiencies. Typically, less than 10 percent of rainfall results in recharge in these months. The lower recharge efficiencies are probably caused by higher evapotranspiration rates in these months.

\section{COMPARISON OF RESULTS}

A summary of the results obtained from the four methods used to estimate recharge in the SRWMD is presented in table 9. Recharge estimates have been rounded to the nearest $5 \mathrm{~cm} / \mathrm{yr}$ to reflect the uncertainty in the estimates. The recharge range for the chloride mass-balance method in unconfined areas is based on the 25th and 75th percentiles of the recharge estimates from the low-intensity land-use area (fig. 6). Thus, the chloride mass-balance estimates shown in table 3 should not be affected by agricultural sources of chloride. The recharge range for the chloride massbalance method in poorly confined areas is based on the estimated value of recharge to the Upper Floridan aquifer in the Lake Barco area. For the water-budget method, the estimates for poorly confined areas are based on the minimum and maximum rates in confined and unconfined areas, respectively. Recharge rates should fall within the upper end of the range in poorly confined areas that lack a well developed network of streams, where many of the streams terminate in sinkholes (sinking streams), or where the intermediate confining unit is otherwise breached. Conversely, 

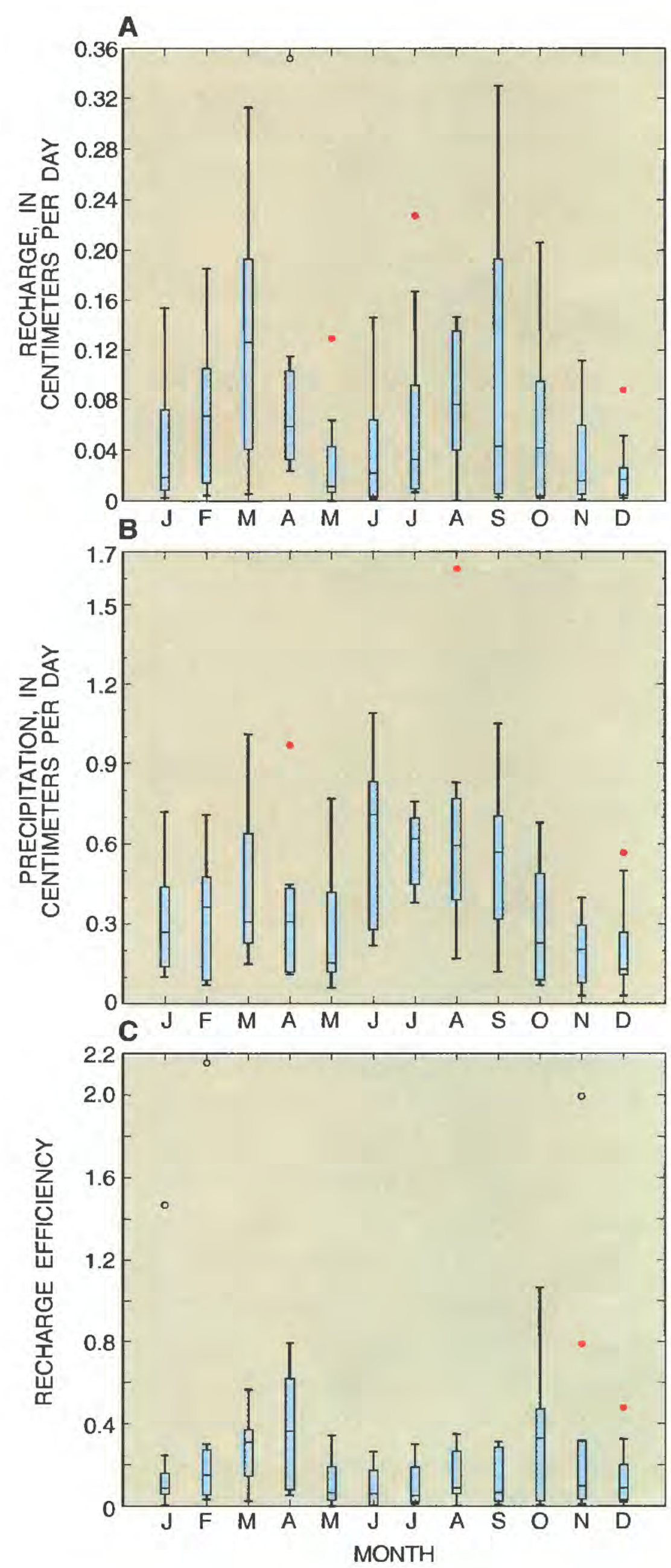

recharge rates will fall within the lower end of the range in poorly confined areas with a well developed network of nonsinking streams. For the hydrometric base-flow method, estimates for each confinement category are based on the 95-percent prediction inter-

\section{EXPLANATION}

Outlier data value more than 3 times the interquartile range outside the quartile

Outlier data value less than or equal to 3 and more than 1.5 times the interquartile range outside the quartile

Data value less than or equal to 1.5 times the interquartile range outside the quartile

75th percentile

Median

25th percentile

Figure 13. Boxplots showing distributions of monthly recharge, precipitation, and recharge efficiency (recharge divided by precipitation) at the Alto Straughn well (location shown in fig. 2).

vals from the previously described regression model that relates recharge to the degree of confinement.

Results obtained from the four methods were generally similar, although the chloride mass-balance estimates computed in this study (for unconfined areas) were lower than the water-budget and hydrometric base-flow estimates (table 9). However, the hydrometric base-flow and water-budget analyses and Lee's (1996) chloride mass-balance results are compelling evidence that the recharge rates in unconfined areas are generally greater than $40 \mathrm{~cm} / \mathrm{yr}$. The hydrometric base-flow estimates in confined areas were also generally lower than the estimates from the waterbudget analysis. Differences in the two estimates may be due to uncertainties in the hydrologic-budget analysis.

Taken together, the results from the different analyses used in this study indicate that recharge rates are probably less than $30 \mathrm{~cm} / \mathrm{yr}$ in confined areas, 40 to $80 \mathrm{~cm} / \mathrm{yr}$ in unconfined areas, and within these two extremes in poorly confined areas. Although the results of this study provide useful estimates of recharge to the Upper Floridan aquifer in the SRWMD, more definitive recharge estimates may be possible through future ground-water modeling studies or studies of evapotranspiration and soil moisture dynamics in selected areas of the SRWMD. 
Table 9. Recharge estimates for confined, poorly confined, and unconfined areas in the Suwannee River Water Management District

\begin{tabular}{|c|c|c|c|}
\hline \multirow{2}{*}{ Method } & \multicolumn{3}{|c|}{$\begin{array}{l}\text { Average-annual recharge rate, } \\
\text { in centimeters per year }\end{array}$} \\
\hline & Confined & $\begin{array}{l}\text { Poorly } \\
\text { confined }\end{array}$ & Unconfined \\
\hline Water budget & 15 to 30 & 15 to 60 & 45 to 60 \\
\hline Chloride tracer & $\begin{array}{l}\text { Not } \\
\text { applicable }\end{array}$ & $35-40^{1}$ & 20 to $35^{2}$ \\
\hline $\begin{array}{l}\text { Hydrometric } \\
\text { base flow }^{3}\end{array}$ & 0 to 20 & 10 to 45 & 50 to 75 \\
\hline $\begin{array}{l}\text { Ground-water } \\
\text { level change }\end{array}$ & $\begin{array}{l}\text { Not } \\
\text { applicable }\end{array}$ & $\begin{array}{l}\text { Not } \\
\text { applicable }\end{array}$ & 20 to 80 \\
\hline
\end{tabular}

${ }^{1}$ Estimated from Lee's (1996) chloride tracer results for the Lake Barco area.

${ }^{2}$ Results from analysis in this study.

${ }^{3}$ Results from regression model of relation between confinement and recharge (excludes direct recharge through sinkholes).

\section{SUMMARY AND CONCLUSIONS}

Estimates of ground-water recharge rates are fundamental to understanding and managing groundwater resources in the Suwannee River Water Management District (SRWMD). This report describes the results of four methods that were used to estimate long-term, average-annual recharge rates to the Upper Floridan aquifer, which is the primary source of freshwater for most uses in the SRWMD. The results obtained from the four methods were generally similar, although the chloride mass-balance estimates of recharge in unconfined areas were lower than the corresponding estimates from the water-budget and hydrometric base-flow methods. Several sources of error in the chloride mass-balance method may account for this discrepancy.

Recharge rates to the Upper Floridan aquifer are controlled in large part by the degree of confinement of the aquifer. Analyses of basin water budgets and streamflow data indicate that recharge is less than 30 centimeters per year (12 inches per year) in areas where the Upper Floridan aquifer is confined by an overlying layer of sediments of low permeability (intermediate confining unit). In unconfined areas, analyses of basin water budgets and streamflow, chloride, and ground-water level data indicate that recharge was probably within a range of 40 to 80 centimeters per year (16-31 inches per year) over most of the SRWMD. In poorly confined areas, where the intermediate confining unit is leaky, recharge rates fall within these two extremes.

\section{REFERENCES}

Aller, L., Bennett, T., Lehr, J., and Petty, R., 1985, DRASTIC: A standardized system for evaluating ground water pollution using hydrogeologic settings: U.S. Environmental Protection Administration Report EPA/600/2-85/018, May 1985, 163 p.

Aucott, W.R., 1988, Areal variation in recharge to and discharge from the Floridan aquifer system in Florida: U.S. Geological Survey Water-Resources Investigations Report 88-4057, 1 sheet.

Baker, L.A., 1991, Regional estimates of atmospheric dry deposition, in Charles, D.F., ed., Acidic deposition and aquatic ecosystems: Regional case studies: New York, Springer-Verlag, app. B, p. 645-653.

Baker, L.A., Brezonik, P.L., and Edgerton, E.S., 1986, Sinks and sources of ions in a soft water, acidic lake: Water Resources Research, v. 22, p. 715-722.

Burnson, Terry, Shoemyen, J.L., Cameron, J.R., Webster, K.B., Oxford Jr., L.C., Ceryak, Ron, Copeland, R.E., Leadon, C.J., and Batchelder, Pat, 1984, Suwannee River Water Management District, in Fernald, E.A., and Patton, D.J., eds., Water Resources Atlas of Florida, Institute of Science and Public Affairs, Florida State University, $291 \mathrm{p}$.

Bush, P.W., and Johnston, R.H., 1988, Ground-water hydraulics, regional flow, and ground-water development of the Floridan aquifer system in Florida and in parts of Georgia, South Carolina, and Alabama: U.S. Geological Survey Professional Paper 1403-C, 80 p.

Clark, W.E., Musgrove, R.H., Menke, C.G., and Cagle, J.W. Jr., 1964, Water resources of Alachua, Bradford, Clay, and Union Counties, Florida: Florida Geological Survey Report of Investigations No. 35, 170 p.

Col, Nolan, 1994, Recharge potential of the Floridan aquifer in the Suwannee River Water Management District, 21 p., 1 pl.

Environmental Science and Engineering, Inc., 1987, Florida acidic deposition study: Five year data summary: Gainesville, Fla., ESE No. 85-186-0106-2110.

Fenneman, N.M., 1938, Physiography of eastern United States, McGraw Hill, New York, 691 p.

Freeze, R.A., and Cherry, J.A., 1979, Groundwater: Englewood Cliffs, N.J., Prentice-Hall, Inc., 604 p.

Grubbs, J.W.. 1995a, Evaluation of ground-water flow and hydrologic budget for Lake Five-O, a seepage lake in northwestern Florida: U.S. Geological Survey WaterResources Investigations Report 94-4145, 42 p. 1995b, Ground-water recharge in Escambia and Santa Rosa Counties, Florida: U.S. Geological Survey Water-Resources Investigations Report 94-4179, 2 pl.

Hendry, C.D., and Brezonik, P.L., 1980. Chemistry of precipitation at Gainesville, Florida: Environmental Science and Technology, v. 14, no. 7, p. 843-849. 
Helsel, D.R., and Hirsch, R.M., 1992, Statistical methods in water resources: Elsevier Science Publishers, 522 p.

Irwin, G.A., and Kirkland, R.T., 1980, Chemical and physical characteristics of precipitation at selected sites in Florida: U.S. Geological Survey Water-Resources Investigations Report 80-81, $70 \mathrm{p}$.

Lee, T.M., 1996, Hydrogeologic controls on the groundwater interactions with an acidic lake in karst terrain, Lake Barco, Florida: Water Resources Research v. 32, no. 4, p. 831-844.

Maddox, G.L., Lloyd, J.M., Scott, T.M., Upchurch, S.B., and Copeland, Rick, 1992, Florida's ground water quality monitoring program: background hydrogeochemistry: Florida Geological Survey Special Publication No. 34, 364 p.

Mahon, G.L., Choquette, A.F., and Sepulveda, A.A., 1997, Potentiometric surface of the Upper Floridan aquifer in the Suwannee River Water Management District, Florida, May and June 1995: U.S. Geological Survey Open-File Report 96-617, 1 sheet.

Marella, R.L., 1995, Water-use by category, county and water management district in Florida, 1950-90: U.S. Geological Survey Open-File Report 94-521, 114 p.

Miller, J.A., 1986, Hydrogeological framework of the Floridan aquifer system in Florida, and in parts of Georgia, Alabama, and South Carolina: U.S. Geological Survey Professional Paper 1403-B, 91 p.

Nilles, M.A., Gordon, J.D., and Schroder, L.J., 1994, The precision of wet atmospheric deposition data from National Atmospheric Deposition Program/National Trends Network sites determined with collocated samplers: Atmospheric Environment, v. 28, no. 6, p. 1121-1128.

Phelps, G.G., 1978, Methods of estimating recharge to the Floridan aquifer in northeast Florida: U.S. Geological Survey Water-Resources Investigations Report 77-109, $19 \mathrm{p}$.

Pinder, G.F., 1969, Determination of ground-water component of peak discharge from chemistry of total runoff: Water Resources Research, v. 5, p. 438-445.
Pollman, C.D., and Canfield Jr., D.E., 1991, Regional case studies: Florida, in Charles, D.F., ed., Acidic deposition and aquatic ecosystems: Regional case studies: New York, Springer-Verlag, app. B, p. 645-653.

Puri, H.S., and Vernon, R.O., 1964, Summary of the geology of Florida and guidebook to the classic exposures: Florida Geological Survey Special Publication No. 5, $312 \mathrm{p}$.

Rumenik, R.P., and Grubbs, J.W., 1996, Low-flow characteristics of Florida streams: U.S. Geological Survey Water-Resources Investigations Report 93-4165, $220 \mathrm{p}$.

Rutledge, A.T., 1991, Computer programs for describing the recession of ground-water discharge and for estimating mean ground-water recharge and discharge from streamflow records: U.S. Geological Survey Water-Resources Investigations Report 93-4121, p. 33-39.

Southeastern Geological Society Ad Hoc Committee on Florida Hydrostratigraphic Unit Definition, 1986, Hydrogeological units of Florida: Florida Bureau of Geology Special Publication No. 28, 9 p.

Stewart, J.W., 1980, Areas of natural recharge to the Floridan aquifer in Florida: Florida Bureau of Geology Map Series 98, 1 sheet.

Toler, L.G., 1965, Use of specific conductance to distinguish two base-flow components in Econfina Creek, Florida: U.S. Geological Survey Professional Paper 525-C, p. C206-C208.

Vacher, H.L., and Ayers, J.F., 1980, Hydrology of small oceanic islands - utility of an estimate of recharge inferred from the chloride concentration of the freshwater lenses: Journal of Hydrology, v. 1980, no. 45, p. 21-37.

Vecchioli, John, Tibbals, C.H., Duerr, A.D., and Hutchinson, C.B., 1990, Ground-water recharge in Florida-a pilot study in Okaloosa, Pasco, and Volusia Counties: U.S. Geological Survey Water-Resources Investigations Report 90-4195, 16 p. 
U.S. Department of the Interior

U.S. Geological Survey

227 N. Bronough Street

Tallahassee, FL 32301-1372

\section{BOOK RATE}

